\title{
The effects of offshoring to low-wage countries on domestic wages: a worldwide industrial analysis
}

\author{
Joanna Wolszczak-Derlacz ${ }^{1}$ - Aleksandra Parteka ${ }^{1}$
}

(c) The Author(s) 2016. This article is published with open access at Springerlink.com

\begin{abstract}
This paper extends the literature on the implications of offshoring for labour markets by investigating its effect on the wages of different skill groups in a broad global context. The analysis draws on input-output data from the WIOD project, and in the panel analysed (13 manufacturing industries, 40 countries, 1995-2009) we account for up to $96 \%$ of the international trade in manufacturing inputs. Being particularly interested in the wage effects of offshoring to low-wage countries (LWC), we use precise LWC classifications (varying across industries and time) to decompose overall offshoring by source country. We use a decomposition of the conventional offshoring measure in order to capture its pure international component, which is further instrumented using a gravity-based strategy. According to the estimation results, the negative impact of offshoring on wages mainly concerns low and medium skilled workers. However, in terms of magnitude, the downward pressure on domestic wages exhibited by offshoring to LWC is relatively small.
\end{abstract}

Keywords Wage $\cdot$ Offshoring $\cdot$ Input-output $\cdot$ Low-wage countries

JEL Classification F14 - F16 · F66 - C67

Electronic supplementary material The online version of this article (doi:10.1007/s10663-016-9352-4) contains supplementary material, which is available to authorized users.

Joanna Wolszczak-Derlacz

jwo@zie.pg.gda.pl

1 Faculty of Management and Economics, Gdańsk University of Technology, Narutowicza 11/12, 80-233 Gdańsk, Poland 


\section{Introduction}

The increasing importance of offshoring (defined conventionally as the geographical separation of production activities across two or more countries, as in the classic paper by Feenstra and Hanson 1999), matched with an improved accessibility of data, has boosted the empirical literature on its effects on domestic labour markets. ${ }^{1}$ The main emphases have been placed on the effects of offshoring on the employment/labour demand structure and wages (including the evolution of the skilled-unskilled wage gap). ${ }^{2}$ So far, the main focus has been put on developed countries, as they are the countries whose labour markets are at risk of "losing" as a consequence of transferring parts of production (or tasks) abroad to less developed destinations. Unsurprisingly, much of the attention has been given to outcomes visible in the US labour market, considering primarily the effects of offshoring to such developing countries as Mexico (e.g., Sethupathy 2013), China or India (e.g. Liu and Trefler 2008), or to the results of occupational exposure to globalization due to rising import competition from China and other developing countries (e.g. Autor et al. 2013; Ebenstein et al. 2014; Acemoglu et al. 2014). Similar analyses have been performed to assess the offshoring response of labour markets in single advanced Western European countries (e.g. UK: Amiti and Wei 2005; Austria: Egger and Egger 2003; Belgium: Michel and Rycx 2012; Denmark: Hummels et al. 2014; Germany: Geishecker and Görg 2008; Baumgarten et al. 2013).

Many factors can affect wages. ${ }^{3}$ In this paper, we focus on the industry-level response of wages paid in domestic industries (in which imported inputs are employed) to offshoring, in particular to low-wage countries (LWC). ${ }^{4}$ However, as will be explained, we adopt a much wider perspective than that taken so far. Before describing our contribution, we will shed some light on the existing related evidence. Given the scope of our paper, we leave aside country-specific analyses

\footnotetext{
${ }^{1}$ A comprehensive review of the offshoring effects on labour markets is provided by Feenstra (2010).

2 An important parallel stream of research underlined the impact of technological progress on wages (especially of low-skilled workers, e.g. through computerization). In particular, skill biased technological change (SBTC), identified as the tendency of new technology to complement skilled-workers and to substitute unskilled labour, can result in labour demand shifts and increase in wage inequalities (among others: Card and Di Nardo 2002). Technical change can be linked to offshoring activity: Baldwin and Robert-Nicoud (2014) demonstrate in their 'integrating framework' that trade in tasks is similar to technical change while Acemoglu et al. (2015) introduce directed technical change into a Ricardian model of offshoring and show that offshoring and technical change are substitutes in the short run but complements in the long run.

3 Several streams of labour economics literature are related to wage determination process, covering such aspects as: the interplay between skill demand and supply (Card and Lemieux 2001; Acemoglu and Autor 2011), wage effects of the assignment of skills to tasks (Autor 2013); job and wage polarisation (Goos et al. 2014); relations between worker and employer in the presence of imperfect competition on labour markets (Manning 2011), decentralisation of wage bargaining (Dahl et al. 2013); collective bargaining and the role of labour unions (Cahuc et al. 2014, 401-478); the evolution of participation rates, part-time work and other factors affecting labour supply (Cahuc et al. 2014, 3-76).

4 Throughout the paper we use the term 'offshoring' to capture the allocation of business activities to another country, assuming that it involves flows of intermediates (inputs) across borders, visible in international input-output tables (Feenstra 1998). Offshoring to low-wage countries (LWC) refers to inputs imported from LWC.
} 
based on worker-level or firm-level micro-data-as surveyed in Crinò (2009) or Castellani et al. (2015). Focusing on industry-level studies, most papers address the impact of the international sourcing of inputs on industry-level outcomes in terms of reduced employment/overall labour demand (e.g. Amiti and Wei 2005 for the UK; Acemoglu et al. 2014 for the US; Cadarso et al. 2008 for Spain; Falk and Wolfmayr 2005, 2008 for a small sample of EU countries; Hijzen and Swaim 2007 for 17 OECD countries; Michel and Rycx 2012 for Belgium). Overall, most of these studies tend to fail to support the view that substantial statistically significant job losses can be observed at the industry level directly due to offshoring. Import competition in industries exposed to foreign competition can have a stronger impact, as illustrated in a study by Acemoglu et al. (2014) — their estimates suggest net job losses in the US of 2.0-2.4 million stemming from the rise in import competition from China over the period 1999-2011.

Additionally, the impact of offshoring on changes in the skill composition of labour demand has been analysed, pointing towards a negative influence on the demand for less skilled workers. Regarding wider panel data studies, FosterMcGregor et al. (2013) employ WIOD data (40 countries, 1995-2009) and find that medium-skilled workers suffer the most in terms of shrinking labour demand as a response to offshoring (similar effects are documented in Timmer et al. 2013). Offshoring of services also appears to raise the relative demand for high- and medium-skilled workers (see Crinò 2012, covering 20 industries and nine Western EU countries over 1990-2004).

Is the source of imports important when assessing the labour market effects of offshoring? Egger and Egger (2003) introduced a crucial distinction between offshoring to low-wage and high-wage countries, while Bernard et al. (2006) distinguished between imports from high-income versus low-income countries. Since then, a division of offshoring by the source country has been employed in other studies too, including ones performed at the industry level. Despite conventional worries, Falk and Wolfmayr (2005) estimate that rising intermediate imports from low-wage countries may account for a relatively small reduction in manufacturing employment of only 0.25 percentage points per year in their sample of seven EU countries (1995-2000), while a study by Falk and Wolfmayr (2008) finds no significant effect of services purchased from low-wage countries on manufacturing employment.

There is not so much broad evidence on the effects of offshoring on wages. The recent micro-level papers investigating the impact of international outsourcing on the wages of individual workers are country-specific and limited to countries with good access to micro-data (such as the US: Ebenstein et al. 2014; Autor et al. 2014; Germany: Geishecker and Görg 2008; Denmark: Hummels et al. 2014; UK: Geishecker and Görg 2013) or limited to very small samples of countries. Again, contrary to common fears, the estimated wage cuts due to outsourcing appear to be rather small in economic terms. ${ }^{5}$ For instance, Geishecker et al. (2010) use data for Germany, the UK and Denmark (1991-1999) and find a small negative and weakly

\footnotetext{
5 This is also confirmed by more general studies about the relationship between trade and wages (e.g. Polgár and Wörz 2010).
} 
statistically significant effect of offshoring on wages in Germany, a positive effect in the UK and no statistically significant effect in Denmark. When they consider different skill categories of workers, a negative effect found only for Germany accrues to low-skilled workers (but it is small ${ }^{6}$ ) while for low-skilled UK and Danish workers they cannot identify any outsourcing effect. For the UK, a sizable negative and statistically significant wage effect stems only from outsourcing to CEEC but it vanishes when put in the perspective of real data. ${ }^{7}$ In their industrylevel study performed for a wide sample of EU27 countries, Parteka and Wolszczak-Derlacz (2015) also conclude that offshoring reduces the wage growth of domestic medium- and low-skilled workers. However, they show that this negative effect is economically small.

Building upon the existing literature briefly summarized above, our aim is to provide worldwide evidence on the offshoring-wage nexus using industry-level data and hopefully complementing the existing studies performed at other levels of detail but limited along the country dimension. We aim to fill some important gaps in the related empirical literature.

First, we consider a long panel of industrial data (13 manufacturing industries in 40 countries over the period 1995-2009 ${ }^{8}$ ) derived from the World Input-Output Database (WIOD_Timmer et al. 2015) which covers between 82 and $96 \%$ of the international trade in intermediate goods (depending on the sector and year of analysis). We thus provide representative evidence on the global trends in offshoring and, in contrast to the many country-level studies, exploit its wage effects in a multi-country setting.

Moreover, given the crucial heterogeneity of workers in international trade analysis (Grossman 2013), we consider the wages of three skill groups separately (low, medium and highly skilled), focusing on the effects on the workers who are potentially most at danger-the low and medium skilled ones. Even though WIOD has already been used (in a more restricted manner) in some related studies (e.g. Foster-McGregor et al. 2013; Schwörer 2013; Parteka and Wolszczak-Derlacz 2015), to the best of our knowledge this is the first time that the response of skillspecific wages to offshoring has been analysed in a worldwide cross-country perspective over a significant time period.

In addition, while we correlate the wage levels of workers with offshoring intensity, we decompose the latter by country of origin. ${ }^{9}$ This is done in order to

\footnotetext{
6 They estimate that on average in Germany a one percentage point increase in outsourcing intensity lowers wages for low-skilled workers by a little more than one percent. The overall effect is small, as over the period analysed average outsourcing increased by 1.6 percent. Hence, outsourcing cumulatively reduced wages in Germany by about 2.5 percent. This result is in line with the estimates by Geishecker and Görg (2008), also for Germany.

7 UK outsourcing to CEEC increased by 0.07 percentage points, which implies a very modest cumulative wage reduction of 2.7 percent over the period analysed (Geishecker et al. 2010, 196).

8 WIOD (release November 2013) provides data for the period 1995-2011, but the statistics needed for the computation of the wages of different skill groups of workers is only available up to 2009.

9 Following the nomenclature used in input-output analysis, 'source country' or 'country of origin' is the country from which inputs are imported (hence, the country to which the offshoring takes place), while 'destination country' is the country where the imported inputs are used.
} 
explicitly check for the effects of offshoring to developing ${ }^{10}$ and low-wage countries (LWC) on domestic wages. In particular, we use four alternative LWC classifications. ${ }^{11}$ Importantly, we go beyond standard very rough groupings of LWC based on comparisons of income per capita or an arbitrary attribution of countries to the low-wage category. Due to the use of industry-level wage data, we obtain flexible classification of LWC over time and by industry. Moreover, drawing on bilateral input-output tables, we directly split imported inputs according to the country of origin of the imports (rather than using a proportional method based on shares of total imports, which is employed instead of using tables of imports by country of origin, as in Falk and Wolfmayr 2008; Hertveldt and Michel 2013). We also allow for changes in the relative positions of LWC over time, and the existence of industry-specific wage advantages.

Finally, we adopt a decomposition of conventional overall offshoring measures (calculated - in the spirit of Feenstra and Hanson 1999-as the sum of imported inputs related to the total value of production of the industry in which they are used) into purely international and domestic components. As Castellani et al. (2013) argue, typical measures of offshoring tend to overestimate the role of international components (imported inputs) and neglect the role played by structural changes and flows of intermediates within the domestic economy. Consequently, the adopted decomposition allows us to distinguish between the wage effects of the international component of outsourcing and the effects of domestic outsourcing practices.

The rest of the paper is organised as follows. In Sect. 2, we present the data used in our empirical analysis, and in Sect. 3 we present some crucial facts concerning the trends in offshoring and wages in the period analysed. Section 4 focuses on the estimated empirical model. Results are presented in Sect. 5 starting from the most general setting and then taking into account specificities of source countries and destination countries. Endogeneity in the wage-offshoring relationship is addressed through the use of a gravity-based instrument. Finally, Sect. 6 concludes.

In a nutshell, the main results of our analysis are the following. We document that in the period analysed the intensity of manufacturing offshoring to LWC rose (on average) from 0.025 to 0.075 of the industry value added. However, we find that increasing offshoring (in particular to LWC) is related to a decrease in the industrylevel wages of domestic low- and medium-skill workers, but this effect, albeit statistically significant, is relatively small. We estimate that, ceteris paribus, a rise in offshoring to LWC of $1 \%$ can be associated with a decline in domestic low (medium) skill workers' wages of approximately $0.08 \%(0.07 \%) .^{12}$

\footnotetext{
10 Throughout the paper, developing countries are defined as low- and middle-income countries, according to the classification by the World Bank, 2014 (see Table 10 in the "Appendix").

11 Two more are used in the robustness check section (see footnote 21). The classifications are obtainable in a separate file as additional online material accompanying the paper.

12 LWC classification 4-see Table 1. Intensity of offshoring measured according to Eq. 1. The values on offshoring refer to weighted averages across 13 manufacturing industries in 40 destination countries, with weights corresponding to industry size (employment)—see Fig. 2. Elasticities based on estimation results reported in Tables 5 and 6.
} 


\section{Data and measurement of offshoring}

Our data come from the World Input-Output Database (WIOD_-described in Timmer et al. 2015), consisting of the World Input-Output Tables, WIOT (release: November 2013) and the WIOD Socio Economic Accounts, SEA (update: July 2014). The database reports industry-specific data on socio-economic accounts (value added, gross output etc.) and international input-output tables across 35 industries and 40 countries (plus the rest of the world). After careful inspection of the data, we chose to deal with a broad country sample but restrict our analysis to the 13 manufacturing industries reporting more reliable statistics and excluding raw materials ${ }^{13}$ (see Tables 9 and 10 in the "Appendix" for a list of the industries and countries). In particular, using information on labour compensation and hours worked over the period 1995-2009 (see footnote 8 ), we compute the real hourly wages expressed in $2005 \mathrm{USD}^{14}$ of three distinct skill groups of workers ( $h$-high-, $m$-medium- and $l$-low-skilled; the classification is based on educational attainment) for each country, industry and time period.

Input-output data serve to compute offshoring measures. In the first instance, using information on imported intermediates from WIOD, we calculate conventional industry-specific offshoring indices (Feenstra and Hanson 1999), defined as the ratio of imported intermediate inputs to the value added in the industry in which they are employed. ${ }^{15}$ In all the specifications, we take into account a broad measure of offshoring, ${ }^{16}$ OFF (also called inter-industry offshoring), which is given by the ratio of intermediate purchases $(m)$ imported by industry $j$ in destination country $i$ at

\footnotetext{
${ }^{13}$ In particular, we exclude from the set of manufacturing industries the sector "Coke, refined petroleum and nuclear fuel", imports of which might not represent offshoring practice but rather a purchase of inputs in the form of natural resources not available domestically. The same approach is adopted, for instance, by Hummels et al. (2014).

14 The original dataset reports labour compensation in current local currencies, so following the OECD method we compute real wages (deflated by a household consumption deflator, $2005=100$, from Penn World Table 8.0), and express them in USD (using 2005 exchange rates from WIOD, Sept 2012 update). An alternative way of obtaining wages comparable across time and countries involves either using current exchange rates or PPPs. Our findings are not sensitive to such changes as the three series of wages are highly correlated (for instance, for low skilled wages the coefficient of correlation between our series of wages and the aforementioned two alternatives equals 0.95 and 0.96 , respectively).

15 We are aware that the measure based on the data on imported intermediate inputs obtained from inputoutput tables should be treated as a proxy of offshoring practice. For example, caveats on indirect offshoring measures are discussed in (Michel and Rycx 2012). We discuss the potential limits of our offshoring indices and how to address them in the robustness section.

16 Alternatively, as put forward by Feenstra and Hanson (1999), a narrow (intra-industry) measure of offshoring could be employed. This measures the share of imported intermediate inputs from the same industry in terms of its value added. Formally, narrow offshoring for industry $j$ is computed as (Hijzen and Swaim 2007): $O F F_{j}^{N}=I_{k=j} / V A_{j}$. However, given caveats of such a measure we considered another formulation of offshoring used in the literature (Hijzen and Swaim 2007; Parteka and Wolszczak-Derlacz 2015), and sometimes called 'differential' outsourcing (Hijzen et al. 2005), covers inputs from all industries $k$ other than $j O F F_{j}^{B}=\sum_{k=1}^{K} I_{k \neq j} / V A_{j}$. The correlation between our preferred measure of offshoring intensity (as in Eq. 1) and differential outsourcing equals 0.72 .
} 
time $t$, supplied by all industries $k=1, \ldots, \mathrm{K}(k=j$ and $\mathrm{k} \neq j)$ to industry $j$ 's value added (VA):

$$
O F F_{i j t}=\frac{\sum_{k=1}^{K} m_{i k j t}}{V A_{i j t}}
$$

This broad measure allows us to capture the inter-industry effects of offshoring on the performance of industries incorporating cross-industry spillovers, which need not be the same as intra-industry effects. ${ }^{17}$

Furthermore, following Castellani et al. (2013), we decompose the offshoring index (1) into its international and domestic components:

$$
O F F_{i j t}=\frac{\sum_{k=1}^{K} m_{i k j t}}{V A_{i j t}}=\underbrace{\left[\frac{\sum_{k=1}^{K} m_{i k j t}}{\sum_{k=1}^{K} d_{i k j t}}\right]}_{\text {IntOUT }} \times \underbrace{\left[\frac{\sum_{k=1}^{K} d_{i k j t}}{V A_{i j t}}\right]}_{\text {DomOUT }}
$$

where $d$ is the value of the inputs coming from domestic industries employed in industry $j$. The first expression is the ratio of imported inputs to domestic ones (IntOUT-international outsourcing) while the second reflects the intensity of domestic outsourcing (DomOUT). ${ }^{18}$ As Castellani et al. (2013) argue, offshoring indices calculated as the share of imported inputs over production (Eq. 1) ignore the role played by structural changes in the domestic economy, reflected in the DomOUT component, and tend to overestimate the role played by sourcing to foreign destinations.

Our database comprises many different countries, so we adopt a gradual analysis, taking into account the heterogeneity of both the source countries (to which offshoring takes place) and the destination countries (where we examine the wage effects of offshoring). In the first instance, we consider flows of intermediates imported from all 40 countries (so we consider all the countries of origin) and then disentangle the effects of offshoring. To do this, the measures defined in Eqs. 1 and 2 are recalculated taking into account the source of imports. In particular, we go beyond the standard consideration of imports from developing countries and explicitly assess the wage effects of offshoring to low-wage countries (LWC), denoted by $O F F_{-} L W C$ or IntOUT_LWC and only take into account inputs imported from LWC.

In the absence of wage data which are comparable across many countries, most previous papers have used a rather indirect way of defining low-wage countries (LWC), assuming that countries with a low income per person also have low wages. The common definition of LWC relies on a comparison of GDP per capita to a benchmark country (e.g. the US) setting some arbitrary threshold. For instance, Federico (2014) defines LWC as countries whose GDP per capita was less than $10 \%$ of US GDP per capita in the final year of his sample; while Bernard et al.

\footnotetext{
17 This view is supported by the findings of Hijzen and Swaim (2007) and Baumgarten et al. (2013), who report modest wage effects of within-industry offshoring and substantial wage effects of offshoring if cross-industry spillovers are allowed for.

18 Castellani et al. (2013) call these components: the imported inputs ratio and structural change.
} 
Table 1 Low-wage countries (LWC) - alternative classifications adopted. Source: own elaboration based on wage data from WIOD and GDP and population statistics from PWT 8.0

\begin{tabular}{|c|c|c|c|c|}
\hline Classification & $L W C_{i j t}=1$ if & $\begin{array}{l}\text { Time } \\
\text { specific }\end{array}$ & $\begin{array}{l}\text { Industry } \\
\text { specific }\end{array}$ & Example \\
\hline (1) & $\begin{array}{l}\mathrm{GDPpc}_{\mathrm{it}} \\
<10 \% \text { of } \\
\mathrm{GDPpc}_{\mathrm{t}}^{\text {US }}\end{array}$ & Yes & No & $\begin{array}{l}\text { 1995: BGR, CHN, } \\
\text { IDN,IND,LTU,LVA,ROU,RUS } \\
\text { 2009: CHN, IND, IDN }\end{array}$ \\
\hline (2) & $\begin{array}{c}\mathrm{w}_{\mathrm{it}}<10 \% \text { of } \\
\mathrm{w}_{\mathrm{t}}^{\mathrm{US}}\end{array}$ & Yes & No & $\begin{array}{l}\text { 1995: BGR, BRA,CHN, } \\
\text { IDN,IND,LTU,ROU,RUS } \\
\text { 2009: BGR, BRA, CHN, IDN, IND,MEX }\end{array}$ \\
\hline (3) & $\begin{array}{c}\mathrm{w}_{\mathrm{ijt}}<10 \% \text { of } \\
\mathrm{w}_{\mathrm{jt}}\end{array}$ & Yes & Yes & $\begin{array}{l}\text { 1995: Industry 15t16: CHN, IDN, IND, RUS } \\
\text { Industry 17t18: BGR, BRA, CHN, IDN, IND, } \\
\text { ROU RUS } \\
\text { 2009: Industry 15t16: BGR, CHN, IND } \\
\text { Industry 17t18: BGR, BRA, CHN, IDN, IND, } \\
\text { MEX, RUS; etc. }\end{array}$ \\
\hline $\begin{array}{l}\text { (4) } \\
\text { [Benchmark } \\
\text { classification] }\end{array}$ & $\frac{\mathrm{w}_{\mathrm{ijt}}<30 \% \text { of }}{\overline{\mathrm{w}_{\mathrm{jt}}}}$ & Yes & Yes & $\begin{array}{l}\text { 1995: Industry 15t16: BGR, BRA, CHN, CZE, } \\
\text { EST, IDN, IND, LTU, LVA, MEX, ROU, } \\
\text { RUS, SVK, TUR; } \\
\text { Industry 17t18: BGR, BRA, CHN, CZE, EST, } \\
\text { HUN, IDN, IND, LTU, LVA, MEX, POL, } \\
\text { ROU, RUS, SVK, TUR; etc. } \\
\text { 2009: Industry 15t16: BGR, BRA, CHN, HUN, } \\
\text { IDN, IND, LVA, MEX, RUS, SVK, TUR } \\
\text { Industry 17t18: BGR, BRA, CHN, HUN, IDN, } \\
\text { IND, LTU, LVA, MEX, POL, ROU, RUS, } \\
\text { SVK, TUR; etc. }\end{array}$ \\
\hline
\end{tabular}

Notes: Classification (2) is based on the comparison of hourly wages reported in industry "Total"; classifications (3) and (4) are based on the comparison of hourly wages reported for single industry. $i$ country, $j$ industry, $t$ time. Full set of LWC classification is included in the electronic supplementary materials

(2006) and Khandelwal (2010) adopt a threshold of $5 \%$ of US GDP per capita. We overcome this limit by using the WIOD socio-economic accounts data, which allow us to compare wages across a wide sample of countries. Hence, an important novelty of our approach lies in the fact that we quantify offshoring to LWC on the basis of a precise identification constructed with wage data at the industry level.

We employ four alternative definitions of low-wage countries (LWC), which are summarized in Table 1. A file containing full set of LWC classifications can be downloaded from the journal's webpage as additional online material accompanying the paper. The first definition is similar to that adopted by Federico (2014), but we take into account changes in relative income per capita ${ }^{19}$ taking place over time (note that in 1995-the first year of our analysis-eight countries were below the threshold, while in 2009 — the last year of analysis—only three were, so keeping this

\footnotetext{
${ }^{19}$ We use dollar-denominated non-PPP adjusted per capita GDP data, from PWT 8.0.
} 
classification constant and basing it only on the final year would have been oversimplistic). Similarly, classifications (2)-(4), based on a direct comparison of wages, allow for changes in relative wage levels over time. Classification (2) defines as low-wage those countries where the average wage (reported in industry "Total") in year $t$ was below $10 \%$ of the US wage level ${ }^{20}$ in year $t$. This classification is constant across industries but varies over time, as some countries might have experienced a convergence of wages towards US levels. However, a decision to outsource parts of production abroad is likely to be based on the evaluation of crossborder labour cost differentials in specific industries, and not in the economy as a whole, so classification (3) is even more detailed. This comparison of wages is performed within every industry: a given country is defined as a LWC for industry $j$ and year $t$ if the wage level in this industry is below the threshold set at $10 \%$ of the US wage in the same industry $j$ and at time $t$. Finally, classification (4) - the most detailed and our preferred one-uses the average sectoral wage in the whole sample of countries as a benchmark (and not the US wage as before): a given country is defined as a LWC for industry $j$ and year $t$ if the wage level in this industry is below a threshold set at $30 \%$ of the average wage ${ }^{21}$ paid globally in the same industry $j$ and at time $t$. The examples shown in Table 1 confirm two things: $(i)$ classification (1) is likely to be biased, and (ii) the cross-industry variability of wages, visible when classifications (3) and (4) are employed, should be taken into account, as some countries are revealed as 'low-wage' only for certain industries. This is clearly visible in Table 11 (in the "Appendix"): in 2009 countries such as Bulgaria and China could be put in the LWC category for all manufacturing sectors, but this is not true in the case of, for instance, countries such as Romania and Turkey.

\section{Descriptive evidence}

Our data confirm a substantial rise in offshoring in recent decades. The manufacturing offshoring intensity in our sample of 40 countries-measured in the broad sense as the ratio of imported intermediate inputs to the value added, as in Eq. (1)—rose from 0.24 in 1995 to $0.30^{22}$ in 2008 (and then there was a drop in 2009 due to the global crisis). This is illustrated in Fig. 1. The common view, nourishing fears of cross-border labour substitution and/or a downward pressure on domestic wages, is that intermediates are sourced mainly from developing countries. Is this really the case? In order to answer this question, we shall first show the

\footnotetext{
${ }^{20}$ We have chosen not to adopt a $5 \%$ threshold, as in Khandelwal (2010), because by doing so only three countries (namely China, India and Indonesia) would have been classified as low-wage countries.

21 As a robustness check, we also adopt two other classifications: modifying the threshold set for our benchmark classification (4) and setting it at $50 \%$ of the average wage; and $100 \%$ of the average wage (hence, LWC are those countries which have sectoral wages below half of the average wage, or below the average wage). Results available from authors upon request.

22 The weighted averages across 40 countries are listed in Table 10, weighted according to sector size (total hours worked by persons engaged). The values refer to imports from these 40 countries (excluding RoW-rest of the world, present in the WIOD data).
} 

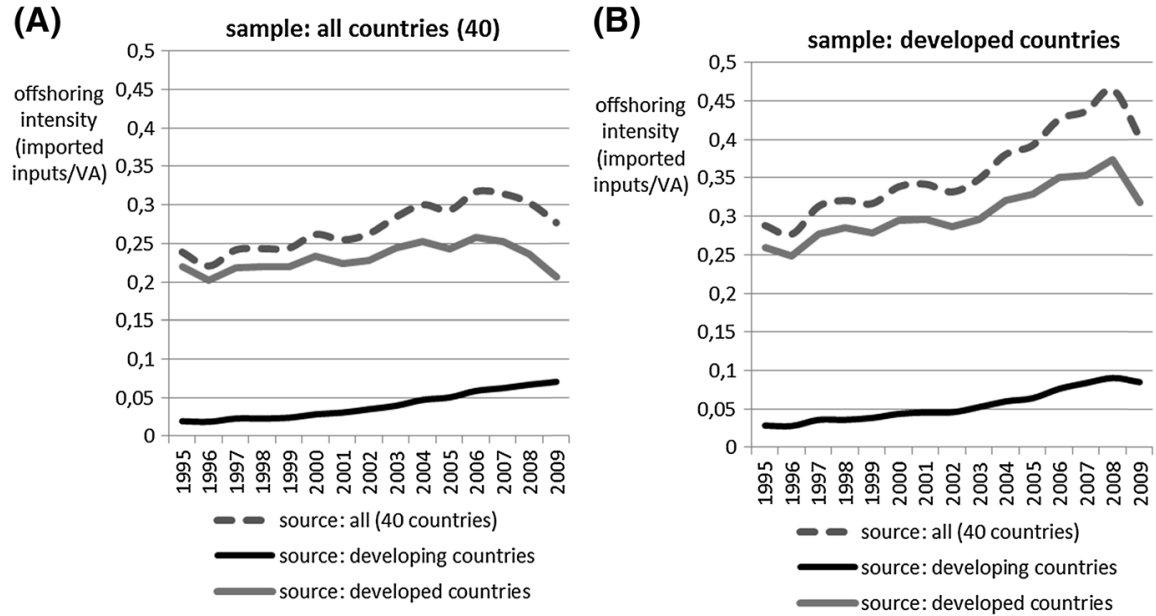

Fig. 1 Trends in manufacturing offshoring-overall and by source countries. Note Offshoring intensity is measured in a broad sense as the ratio of imported intermediate inputs to the value added (Eq. 1). Weighted averages across 13 manufacturing industries (Table 9 in the "Appendix"). The weights correspond to industry size (employment). a all 40 destination countries, b only developed countries retained as destination countries (countries listed in Table 10 in the "Appendix"). Source: own elaboration with input-output data from WIOD

Table 2 Imported manufacturing intermediates split by country of origin, shares (in \%). Source: own elaboration with input-output data from WIOD

\begin{tabular}{lccccc}
\hline Countries of origin & \multicolumn{2}{l}{$\begin{array}{l}\text { A. Sample of destination countries: } \\
\text { all countries (40) }\end{array}$} & & \multicolumn{2}{l}{$\begin{array}{l}\text { B. Sample of destination countries: } \\
\text { developed countries (31) }\end{array}$} \\
\cline { 2 - 3 } & 1995 & 2009 & & 1995 & 2009 \\
\hline Developing countries & 8.7 & 19.1 & 9.1 & 19.2 \\
China & 2.5 & 10.4 & & 2.6 & 10.6 \\
India & 0.8 & 1.3 & & 0.8 & 1.3 \\
Developed countries & 91.3 & 80.9 & 90.9 & 80.8 \\
G8 & 61.5 & 49.3 & 60.9 & 48.9 \\
US & 14.1 & 12.2 & 12.5 & 9.9 \\
EU15 & 50.8 & 44.2 & 53.9 & 50.1 \\
TOTAL (40) & 100 & 100 & 100 & 100 \\
\hline
\end{tabular}

Notes: The statistics present the shares (in \%) of imported intermediates from specific regions/countries of origin in the overall value of intermediate good imports from all 40 countries analysed (listed in Table 10 in the "Appendix"). Division between developing and developed countries from the World Bank

evidence concerning the classic developing/developed countries division and then move on to using a country grouping based on explicit wage information.

Table 2 reports the relative shares of different source countries (or country groups) in the total value of intermediates imported by the 40 countries in our sample (panel A) or only by developed countries (panel B) in the border years of our analysis (1995 and 2009). In reality, the majority of intermediate goods 
(approx. $81 \%$ in 2009) are still imported from developed countries. However, a change in the direction of offshoring is evident: the share of imports of intermediates from developing countries more than doubled. In 2009, over $10 \%$ of all manufacturing intermediates came from China (four times more than in 1995). India's share is significantly lower, but despite its specialization in services offshoring, this country managed to improve its position as a source market of intermediate manufacturing goods. Considering developed countries as countries of origin, the importance of the EU15 and G8 as source markets of intermediate goods strongly decreased, whereas for the U.S. the fall was less pronounced but still visible. The figures reported in panel A and panel B are fairly similar, with only a few differences concerning a slightly greater relative importance of the EU15 as sources of imports for developed countries than in the overall sample (especially in 2009, when half of the inputs imported by developed countries came from the EU15).

Figure 1 shows how the intensity of manufacturing offshoring to developing countries evolved in time in comparison with overall offshoring intensity and offshoring to developed countries. Here, the numbers refer to the share of the value of imported inputs with respect to the industry value added (calculated as in Eq. 1). Plot A shows the trends typical for all 40 destination countries in our sample, while plot B refers to the restricted sample of destination countries: only developed countries. When the sample is restricted (plot B), we note that the offshoring intensity in this group is generally higher. In line with Table 2, it is notable that offshoring to developed countries accounts for most overall offshoring (but a decline, probably due to the global crisis, is clearly visible). However, offshoring to developing countries was constantly growing (for all the 40 countries in our sample - plot A-in 1995 on average it accounted for $2 \%$ of manufacturing value added, and already for $7 \%$ in 2009; for developed countries-plot B-the values are $3 \%$ in 1995 and $8.5 \%$ in 2009 respectively).

Given our interest in offshoring to low-wage markets, Fig. 2 shows the trends concerning offshoring intensity calculated only with imports from LWC. Independently of the LWC classification adopted (see Table 1), a constant rise in offshoring to countries characterized by low wages is observed. The solid black line, referring to our benchmark LWC classification (4) and based on a comparison of wages within industries and with respect to the global level, indicates that the offshoring to LWC directed to the 40 countries in our sample (plot A) rose from $2.5 \%$ of value added in 1995 to $7.5 \%$ in 2009. Plot B shows that the offshoring from developed countries to LWC rose from $2.8 \%$ of the developed countries' value added in 1995 to $8.5 \%$ in 2009 .

An important question thus emerges: is there any relationship between the rise in offshoring to LWC and the wages paid in domestic industries sourcing parts of their production processes to LWC? Typically, low- and medium-skilled workers (whose tasks are easily outsourced) in developed countries are afraid of pressure from foreign low-wage competitors. Figure 3 shows simple plots relating the log of low-skilled workers' wages paid in manufacturing industries in developed countries to industry exposure to offshoring. Plot A, obtained with the overall offshoring measure, shows that there is practically no relationship between the two 
(A)

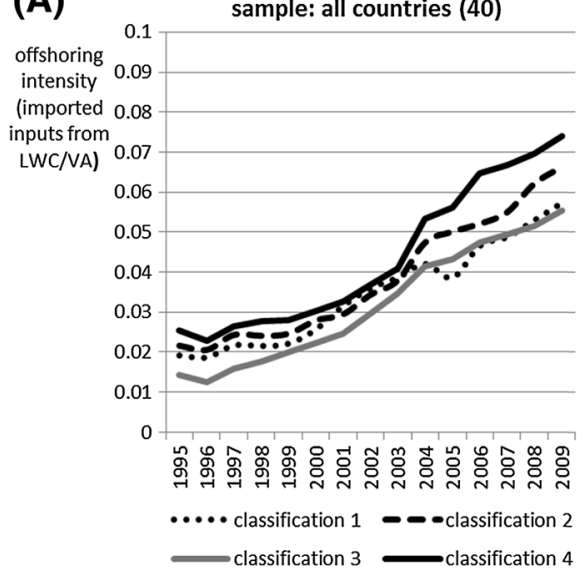

(B)

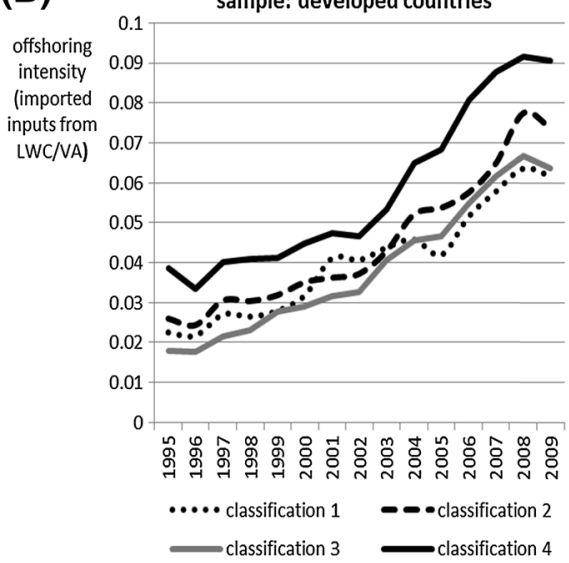

Fig. 2 Trends in manufacturing offshoring to low-wage countries (LWC). Note Offshoring intensity measured in a broad sense as the ratio of intermediate inputs imported from low-wage countries (classifications in Table 1) to the value added. Weighted averages across 13 manufacturing industries (Table 9 in the "Appendix"). The weights correspond to industry size (employment). a all 40 destination countries, b only developed countries retained as destination countries (countries listed in Table 10 in the "Appendix"). Source: own elaboration with input-output data from WIOD

(A) overall offshoring (all source countries)

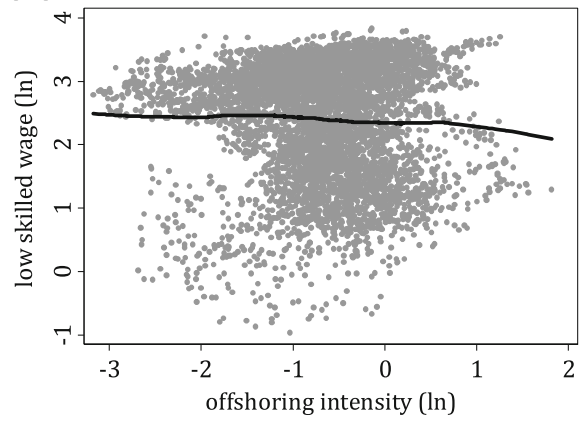

(B)

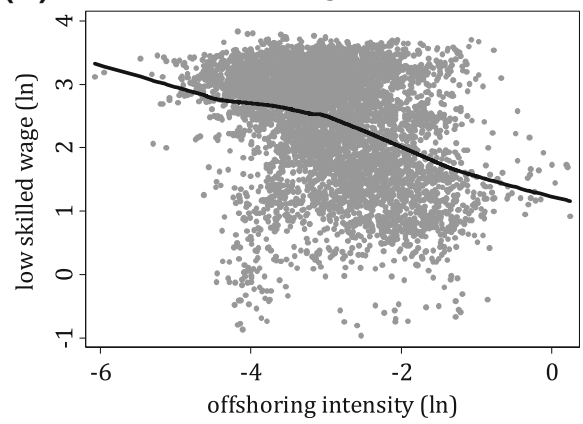

Fig. 3 Relationship between offshoring intensity and low skilled wages in developed countries. Note Offshoring measured in a broad sense as the ratio of imported intermediate inputs to the value added (Eq. 1). Sample analysed: 13 manufacturing industries (Table 9 in the "Appendix"), 31 developed countries (Table 10 in the "Appendix"), 1995-2009. a offshoring to all 40 countries, b: offshoring only to LWC (according to classification 4). The lines correspond to LOWESS approximations ( $\operatorname{span}=0.8$ ), the dots represent country-industry-year observations. Source: own elaboration with input-output data from WIOD

variables. Here, offshoring is measured independently of the type of source country of the imported inputs. However, when we account for offshoring to LWC only (plot B), a negative relationship emerges. This evidence, so far unconditional on any other factors possibly affecting wages, will be tested with the formal empirical model. 


\section{The model}

\subsection{Theoretical foundations}

The description of mechanisms relating trade (including trade in parts and components due to offshoring) and wages is present in several strands of international economics literature. ${ }^{23}$ Importantly from the point of view of our empirical analysis, the theories evolved in the direction of showing that wage effects stemming from outsourcing/trade shocks can vary across skill classes of workers.

The first wave of research on trade and wages (e.g. Borjas et al. 1997) relied on Hecksher-Ohlin (HO) framework which emphasizes differences in factor intensities across sectors and factor endowments across countries. Less educated workers (whose tasks are easier to be moved to foreign destinations) have been typically perceived to be more at risk of experiencing a wage loss. As we will show in the empirical analysis, this indeed is true (albeit the effect is small). Stolper-Samuelson theorem was used to address the implications of trade (especially with less developed countries) for the labour markets: trade-induced industry level shocks result in changes in goods prices, which in turn change factor prices (wages). The 'cone of diversification' was assumed to be fixed, so the next class of models (e.g. Feenstra and Hanson 1999; Grossman and Rossi-Hansberg, GRH 2008) allowed for the change in the set of goods produced in the country. In particular, GRH introduced the 'task trade' approach and focused on the adjustment of the bundle of domestically provided intermediate inputs, resulting from the division of tasks into those which are performed at home and those which are offshored. In terms of guidelines for the empirical analysis, GRH show that there is no unique outcome of trade/offshoring shock: e.g. the evolution of low skill wages will depend on the net effects of offshoring on productivity, prices and labour supply.

In general, the attempts in the recent years have been focused on building models which incorporate features of various theoretical frameworks, moving the theory as close to the reality as possible. The Ricardian framework (focusing on productivity differences across countries), has been modified by Rodríguez-Clare (2010) who embodied the GRH approach in a Ricardian model à la Eaton and Kortum (2002). There have also been attempts to match HO and Ricardian explanations. Burstein and Vogel (2011) present an interesting unifying framework which links traditional mechanism featuring sectoral productivity and factor endowment differences with the development of new-new trade theory. They incorporate firm heterogeneity into the modelling of the link between globalization and factor prices. Wages are defined by firm productivity: more productive firms use more intensively high skilled labour, so free trade affects wages through Melitz-type mechanism of firm selection and within-industry shifts of employment towards the most productive firms. Finally, Baldwin and Robert-Nicoud (2014) proposed an analytical model in which both trade in goods and trade in tasks arise, so they matched $\mathrm{HO}$ and GRH frameworks.

\footnotetext{
23 See Baldwin and Robert-Nicoud (2014) for a recent review of the related theoretical literature on the effects of trade in intermediate goods.
} 
Our empirical specification is rooted in the Ricardian model of skills, tasks and technologies presented by Acemoglu and Autor (2011). ${ }^{24}$ They explicitly distinguish between tasks and skills, with the former understood as units of work activity that produce output, and the latter as workers' endowments of capabilities for performing various tasks. The model incorporates three types of labour: $h$-high-, $m$-medium- and $l$-low-skilled, all of which can perform given tasks, with the assumption that more complex tasks are performed by high-skilled workers, routine tasks by middle-skilled and manual by low-skilled labour. ${ }^{25}$ Generally, tasks can be performed by workers with different types of skills, automated using machines, or offshored and performed by workers in other countries. This concept of offshoring competing for tasks follows the model in Grossman and Rossi-Hansberg (2008).

To sum up, the wages of workers with different skills are defined simply as a function of the labour supply $\left(L_{s}\right)$ and task assignments $\left(I_{s}\right)$, with $s=\{h, m, l\}$. The allocation of tasks is further determined by capital $(K)$, which can also supply tasks by substituting labour and through offshoring opportunities: $I_{s}=\mathrm{f}(O F F)$. This yields the skill-specific wage function: $W_{s}=f\left(L_{s}, K, O F F\right)$, which is the basis of our empirical setting.

\subsection{Empirical specification}

In order to empirically examine the link between offshoring and wages, we estimate different variants of the following regression:

$$
\begin{aligned}
\ln w_{s i j t}= & \alpha+\beta_{1} \ln k_{i j t}+\beta_{2} \ln L_{s i j t}+\beta_{3} \ln O F F_{i j t-1}+D_{i t}+D_{i j}+D_{t}+\varepsilon_{s i j t} \\
& \vee s=\{h, m, l\}
\end{aligned}
$$

where $i$ denotes the country, $j$ the industry, $t$ is time and $s$ is the skill category. Variable $k$ refers to the capital to labour ratio, ${ }^{26} L$ is the total number of hours worked per person engaged and $O F F$ is the measure of offshoring intensity defined in (1). To take into account a possible time delay between offshoring and wage adjustment, the offshoring intensity $(O F F)$ is introduced as a lagged variable (the

\footnotetext{
${ }^{24}$ We present here only the basic assumptions of this model. For the detail mathematical notation of the model and the exact steps to obtain the wage equation, see Acemoglu and Autor (2011, 1096-1147).

${ }^{25}$ In the recent literature dealing with labour market consequences of cross border production sharing, medium skill workers (performing routine tasks), are often perceived to be at risk. This phenomenon is linked to the polarisation of labour markets (Goos and Manning 2003) observed in the US (Autor and Dorn 2013; Autor et al. 2015) and in European countries (Goos et al. 2014; Michaels et al. 2014). The polarization is generally explained by "computerization of routine job tasks which may lead to the simultaneous growth of high-education, high-paid jobs at one end and low-education, low-wage jobs at the other end, both at the expense of middle-wage, middle-education jobs" (Autor 2015, 12). Employment polarisation implies the shift of employment and earnings from mid-level wage jobs to both high- and low-wage jobs while wage polarization refers to earnings growth at the tails of the distribution. Goos et al. (2014) provide a theoretical framework in which they distinguish between different channels driving polarisation: routine-biased technological change (RBTC) and offshoring.

${ }^{26}$ In the absence of direct skill-specific productivity data, we assume that productivity is related to the capital intensity of the industry (captured by variable $k$ ) and, following Acemoglu and Autor (2011), we assume that workers' productivity follows a positive time trend (time dummies, country-sector and country-time effects are included in the model).
} 
same approach is used in Ebenstein et al. 2014). In order to pick up any other unmeasurable specific effects (e.g. technological change, business cycle), we include a set of year dummies, as well as country-time dummies and countryindustry fixed effects. ${ }^{27}$

In an augmented specification we also include the offshoring components (DomOUT and IntOUT-domestic and international outsourcing) obtained from decomposition (2):

$$
\begin{aligned}
\ln w_{s i j t}=\alpha+\beta_{1} \ln k_{i j t}+\beta_{2} \ln L_{s i j t}+\beta_{3} \ln D o m O U T_{i j t-1}+\beta_{4} \ln I n t O U T_{i j t-1}+D_{i t}+D_{i j}+D_{t}+\varepsilon_{s i j t} \\
\vee s=\{h, m, l\}
\end{aligned}
$$

Finally, to allow for the possibility that offshoring to low-wage countries (LWC) might have different effects to offshoring to high-wage countries (HWC), we include intermediate imports from LWC and HWC as separate regressors, yielding the following equation:

$$
\begin{aligned}
\ln w_{s i j t}=\alpha & +\beta_{1} \ln k_{i j t}+\beta_{2} \ln L_{s i j t}+\beta_{3} \ln \text { DomOUT } T_{i j t-1}+\beta_{4} \ln I n t O U T_{-} L W C_{i j t-1} \\
& +\beta_{5} \ln I n t O U T_{-} H W C_{i j t-1}+D_{i t}+D_{i j}+D_{t}+\varepsilon_{s i j t} \\
& \vee s=\{h, m, l\}
\end{aligned}
$$

\section{Results}

\subsection{Overall effect of offshoring on wages-all source countries, full sample of destination countries}

In this section we present the results of the most general estimation of the empirical models (Eqs. 3 and 4) taking into account the full sample of countries and offshoring independently of the source country of imports. We start with a fixed effects estimator (which allows for time-invariant country-industry specific effects). Table 3 presents the estimation results of the wage regression model for low(Columns 1 and 2), medium- (Columns 3 and 4) and high-skilled workers (Columns 5 and 6). As predicted by theory, for all the skill categories we obtain statistically significant and positive parameters associated with the capital-labour ratio $(k)$ and negative parameters in the case of skill-specific labour supplies $(L)$. Offshoring intensity is, however, our main variable of interest. OFF (calculated as in Eq. 1), appears to have a significant negative impact on the wages of low-, medium- and high-skilled workers employed in domestic manufacturing sectors. However, as reported in columns 2, 4 and 6, when $O F F$ is decomposed into pure international and domestic parts, in the empirical model (4), then the negative and statistically

\footnotetext{
27 Due to the data constraints we were not able to include into our model the division of capital stock into ICT and a non-ICT elements with the ICT component capturing directly the effects of SBTC (as it was done e.g. by Michaels et al. 2014). Following, Foster-McGregor et al. (2013) we control for SBTC indirectly through the inclusion of a set of dummies and fixed effects.
} 
Table 3 The impact of global offshoring on wages $\left(\ln w_{s i j t}\right)$-FE estimation. Source: own calculations with data from WIOD

\begin{tabular}{|c|c|c|c|c|c|c|}
\hline & \multicolumn{6}{|c|}{ Sample: all destination countries (40) } \\
\hline & \multicolumn{2}{|c|}{ Low-skill wage } & \multicolumn{2}{|c|}{ Medium-skill wage } & \multicolumn{2}{|c|}{ High-skill wage } \\
\hline & (1) & (2) & (3) & (4) & (5) & (6) \\
\hline \multirow[t]{2}{*}{$\ln k_{i j t}$} & $0.398 * * *$ & $0.398 * * *$ & $0.312 * * *$ & $0.311 * * *$ & $0.315^{* * *}$ & $0.315^{* * * *}$ \\
\hline & [0.044] & {$[0.044]$} & {$[0.038]$} & {$[0.038]$} & {$[0.038]$} & {$[0.037]$} \\
\hline \multirow[t]{2}{*}{$\ln L_{s i j t}$} & $-0.074 * *$ & $-0.077 * *$ & $-0.176^{* * *}$ & $-0.179 * * *$ & $-0.191 * * *$ & $-0.194 * * *$ \\
\hline & {$[0.035]$} & {$[0.034]$} & {$[0.032]$} & {$[0.032]$} & {$[0.034]$} & {$[0.033]$} \\
\hline \multirow[t]{2}{*}{$\ln O F F_{i j t-1}$} & $-0.087 * * *$ & & $-0.079 * * *$ & & $-0.062 * * *$ & \\
\hline & {$[0.023]$} & & {$[0.022]$} & & {$[0.024]$} & \\
\hline \multirow[t]{2}{*}{$\ln \operatorname{DomOUT}_{i j t-1}$} & & -0.034 & & -0.013 & & 0.02 \\
\hline & & {$[0.032]$} & & {$[0.031]$} & & {$[0.030]$} \\
\hline \multirow[t]{2}{*}{$\ln I n t O U T_{i j t-1}$} & & $-0.047 *$ & & -0.037 & & -0.013 \\
\hline & & {$[0.024]$} & & {$[0.024]$} & & {$[0.025]$} \\
\hline $\mathrm{R}^{2}$ & 0.404 & 0.398 & 0.395 & 0.389 & 0.331 & 0.328 \\
\hline Observations & 7209 & 7209 & 7221 & 7221 & 7205 & 7205 \\
\hline
\end{tabular}

Notes: Constant included-not reported. Robust standard errors in parentheses, clustered at the countryindustry level. Statistically significant at $* * * 1$, ** 5, * 10 percent level. In all specifications, year dummies, country-industry and country-year fixed effects are included. Estimates obtained with the broad offshoring measure. Global offshoring: countries of origin = all 40 countries listed in Table $10+$ Rest of the World

significant effect of IntOUT on wages is only sustained in the case of low-skilled labour. Additionally, domestic outsourcing (DomOUT) does not affect the wages of any skill category in a statistically significant way.

However, we are aware of potential endogeneity issues in the models estimated. First, regarding labour $(L)$ as the explanatory variable, industry-level wages and employment by skill level may be determined simultaneously. Second, there can be a two-way relationship between offshoring and wages e.g. the level of wages where the production is offshored is crucial. On the basis of endogeneity tests (Table 12 in the "Appendix") we cannot reject the hypothesis that $L$ and DomOUT can be treated as exogenous, while exogeneity of the offshoring variables (OFF, IntOUT) is strongly rejected.

To address this issue, we adopt a gravity-based strategy (extending Frankel and Romer's 1999 traditional approach to sectoral-level data as in Di Giovanni and Levchenko 2009) to construct an instrument for our offshoring indices. Using the data on bilateral imports in the panel analysed (40 countries, 13 manufacturing industries, 1995-2009), we estimate a gravity model in which bilateral trade in intermediate goods is regressed on the log of the reporter's and the partner's value added, the log of the distance between the countries, and dummy variables for a common land border, common official language, common currency, former colonial relationship and membership in a common regional trade agreement. For each of the industries and reporter countries, the predicted values of trade flows are then 
summed across all the partner countries or, alternatively, across selected partners to obtain an instrument for intermediate goods trade with the groups considered in our analysis (e.g. LWC). ${ }^{28}$

The IV results, corresponding to the Table 3 FE estimations, are reported in Table 4. The instrument validity is confirmed by under-identification and weak identification tests. In this specification, only offshoring $(O F F)$, measured globally, has a significant and negative impact on the wages of low- and medium-skilled workers, with low estimated elasticity (approx. -0.1).

The results in Table 3 and Table 4 should be treated as a first step in the deeper examination of the offshoring-wage nexus. In the first instance, we shall take into account the characteristics of the countries from which inputs are imported.

From now on, we will concentrate on the results obtained with the use of IV estimates employing the gravity-based instrument.

\subsection{Exploring the heterogeneity of source countries: the wage effect of offshoring to low-wage countries}

Tables 5 and 6 report the results referring to the effects of offshoring when we distinguish between intermediate imports from low-wage (LWC) and high-wage countries (HWC). In order to assure the maximum level of detail and to allow for structural change effects and domestic outsourcing, we report the results obtained once the decomposition (Eq. 2) of the general $O F F$ measure is taken into account using empirical specification (5). We focus on the wages of workers who are potentially most at danger: the low- (Table 5) and medium-skilled (Table 6). ${ }^{29}$

The subsequent columns in Table 5 show the results of the regression estimations employing alternative classifications of LWC (summarized in Table 1-classification 4 is our preferred one) for the low-skilled workers. Whichever alternative classification of LWC we use, we find a negative effect of offshoring to LWC on the wages of low-skilled labour. The estimated elasticities are, however, very small (in the absolute terms below 0.1). For instance, sticking with classification (4) of LWC and when we account for domestic structural change (results in column 4 of Table 5), a rise in offshoring to LWC of $1 \%$ is associated with a decrease in the wages paid to domestic low-skilled workers of only $0.085 \%$. There is no significant impact of offshoring to HWC. Additionally, a negative effect of domestic fragmentation on wages emerges (a negative parameter associated with DomOUT).

\footnotetext{
${ }^{28}$ The data on bilateral trade in intermediate goods come from WIOT (release: November 2013), the data on value added from the WIOD Socio Economic Accounts, SEA (update: July 2014) and the information on all the other regressors are taken from CEPII databases. The Poisson Pseudo Maximum Likelihood method-PPML (Santos Silva and Tenreyro 2006) is employed to estimate the gravity equation separately for each of the sectors. Thanks to this we do not lose information about zero trade flows. A similar approach is employed, e.g., by Parteka and Wolszczak-Derlacz (2015).

29 The corresponding results concerning high-skilled workers are presented in Table 13 in the "Appendix". In general, have intermediate imports purchases neither from LWC nor from HWC a statistically significant impact on the wages of domestic high-skilled workers. Only when classification 1 is employed the parameter is statistically significant but, as described in Sect. 2, such a classification is over simplistic.
} 


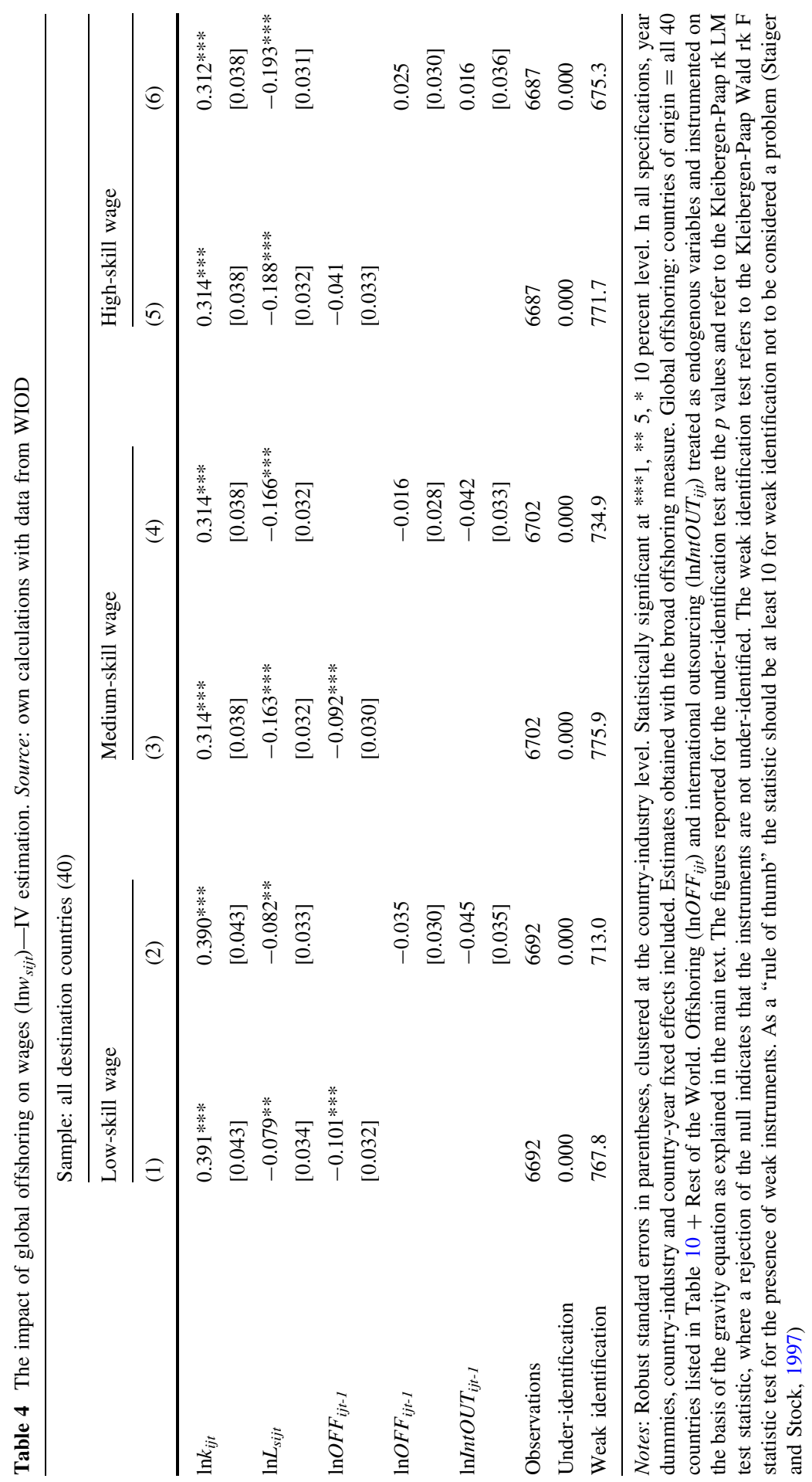


Table 5 The impact of offshoring on wages of low-skilled workers $\left(\ln w_{s i j t}\right)$-IV estimation, source countries split into low-wage and high-wage countries (LWC and HWC). Source: own calculations with data from WIOD

\begin{tabular}{|c|c|c|c|c|}
\hline & \multicolumn{4}{|c|}{ Sample: all destination countries (40) } \\
\hline & $\begin{array}{l}\text { LWC class. } 1 \\
\text { (1) }\end{array}$ & $\begin{array}{l}\text { LWC class. } 2 \\
\text { (2) }\end{array}$ & $\begin{array}{l}\text { LWC class. } 3 \\
\text { (3) }\end{array}$ & $\begin{array}{l}\text { LWC class. } 4 \\
\text { (4) }\end{array}$ \\
\hline \multirow[t]{2}{*}{$\ln k_{i j t}$} & $0.356 * * *$ & $0.363 * * *$ & $0.366^{* * *}$ & $0.381 * * *$ \\
\hline & {$[0.040]$} & {$[0.041]$} & {$[0.042]$} & {$[0.042]$} \\
\hline \multirow[t]{2}{*}{$\ln L_{s i j t}$} & $-0.112 * * *$ & $-0.101 * * *$ & $-0.098 * * *$ & $-0.083^{* *}$ \\
\hline & {$[0.032]$} & {$[0.032]$} & {$[0.033]$} & {$[0.033]$} \\
\hline \multirow[t]{2}{*}{$\ln$ DomOUT $_{i j t-1}$} & $-0.070 * *$ & $-0.073 * *$ & $-0.063 *$ & $-0.061 *$ \\
\hline & {$[0.032]$} & {$[0.032]$} & {$[0.032]$} & {$[0.032]$} \\
\hline \multirow[t]{2}{*}{$\ln I n t O U T_{-} L W C_{i j t-1}$} & $-0.077 * * *$ & $-0.075 * * *$ & $-0.077 * * *$ & $-0.085 * * *$ \\
\hline & {$[0.011]$} & {$[0.014]$} & {$[0.015]$} & {$[0.018]$} \\
\hline \multirow[t]{2}{*}{$\ln I n t O U T \_H W C_{i j t-1}$} & -0.025 & -0.038 & -0.008 & -0.004 \\
\hline & {$[0.032]$} & {$[0.032]$} & {$[0.035]$} & {$[0.034]$} \\
\hline Observations & 6692 & 6692 & 6692 & 6692 \\
\hline Under-identification & 0.000 & 0.000 & 0.000 & 0.000 \\
\hline Weak identification & 150.1 & 163.8 & 168.2 & 137.6 \\
\hline
\end{tabular}

Notes: Robust standard errors in parentheses, clustered at the country-industry level. Statistically significant at $* * * 1, * * 5, * 10$ percent level. In all specifications, year dummies, country-industry and country-year fixed effects included. Estimates obtained with the broad offshoring measure. International outsourcing ( $\ln I n t O U T_{-} L W C_{i j t}$ and $\left.\ln I n t O U T_{-} H W C_{i j t}\right)$ treated as endogenous variables and instrumented on the basis of the gravity equation, as explained in the main text. The figures reported for the underidentification test are the $p$ values and refer to the Kleibergen-Paap rk LM test statistic, where a rejection of the null indicates that the instruments are not under-identified. The weak identification test refers to the Kleibergen-Paap Wald rk F statistic test for the presence of weak instruments. As a "rule of thumb" the statistic should be at least 10 for weak identification not to be considered a problem (Staiger and Stock, 1997)

In Table 6 we present the analogous results for medium-skilled labour. In general, the results for medium-skilled workers and similar to those for the low skilled. However, the magnitude of the parameter is slightly lower e.g. for classification (4) for medium-skilled workers it is equal to -0.068 (column 4 of Table 6). ${ }^{30}$

\subsection{Exploring the heterogeneity of destination countries: the effect of offshoring on wages in developed countries}

The big advantage of our dataset is its wide country coverage (40 countries). We have already shown the importance of distinguishing the country of origin of intermediate imports but we have not yet explored the heterogeneity on the left-

\footnotetext{
${ }^{30}$ As described in the introduction, papers employing industry level data and showing negative consequences on medium skilled workers deal primarily with the effects of outsourcing on employment or labour demand structure (Foster-McGregor et al. 2013; Timmer et al. 2013). In our paper, we focus on the effect on wages, so the results shown in the two strands of literature are not directly comparable.
} 
Table 6 The impact of offshoring on wages of medium-skilled workers $\left(\ln w_{s i j t}\right)$-IV estimation, source countries split into low-wage and high-wage countries (LWC and HWC). Source: own calculations with data from WIOD

\begin{tabular}{|c|c|c|c|c|}
\hline & \multicolumn{4}{|c|}{ Sample: all destination countries (40) } \\
\hline & $\begin{array}{l}\text { LWC class. } 1 \\
\text { (2) }\end{array}$ & $\begin{array}{l}\text { LWC class. } 2 \\
\text { (3) }\end{array}$ & $\begin{array}{l}\text { LWC class. } 3 \\
\text { (4) }\end{array}$ & $\begin{array}{l}\text { LWC class. } 4 \\
\text { (5) }\end{array}$ \\
\hline \multirow[t]{2}{*}{$\ln k_{i j t}$} & $0.292 * * *$ & $0.298 * * *$ & $0.299 * * *$ & $0.307 * * *$ \\
\hline & {$[0.037]$} & {$[0.038]$} & {$[0.038]$} & {$[0.038]$} \\
\hline \multirow[t]{2}{*}{$\ln L_{s i j t}$} & $-0.183 * * *$ & $-0.176^{* * *}$ & $-0.175^{* * *}$ & $-0.166^{* * *}$ \\
\hline & {$[0.031]$} & {$[0.032]$} & {$[0.032]$} & [0.031] \\
\hline \multirow[t]{2}{*}{$\ln$ DomOUT $T_{i j t-1}$} & $-0.051 *$ & $-0.054 *$ & -0.040 & -0.041 \\
\hline & {$[0.030]$} & {$[0.030]$} & [0.031] & {$[0.031]$} \\
\hline \multirow[t]{2}{*}{$\ln I n t O U T_{-} L W C_{i j t-1}$} & $-0.055 * * *$ & $-0.044 * * *$ & $-0.049 * * *$ & $-0.068 * * *$ \\
\hline & {$[0.010]$} & {$[0.011]$} & {$[0.013]$} & {$[0.016]$} \\
\hline \multirow[t]{2}{*}{$\ln I n t O U T \_H W C_{i j t-1}$} & -0.044 & -0.060 & -0.028 & -0.016 \\
\hline & [0.029] & {$[0.059]$} & [0.032] & {$[0.031]$} \\
\hline Observations & 6702 & 6702 & 6702 & 6702 \\
\hline Under-identification & 0.000 & 0.000 & 0.000 & 0.000 \\
\hline Weak identification & 156 & 165 & 173 & 145 \\
\hline
\end{tabular}

Notes: As below Table 5

hand side of the estimated equations (Eqs. 3-5). Given that approximately threequarters of imported manufacturing intermediates are directed to developed countries, ${ }^{31}$ and following worries of workers in these countries concerning foreign competition, we will explicitly deal with the effects of offshoring on wages in developed economies. ${ }^{32}$

Table 7 presents the results obtained for the restricted sample of destination countries (excluding developing countries), corresponding to the estimates concerning all 40 countries reported in Table 4. Overall offshoring (OFF, imports from all countries-independently of type) turn out to exhibit a downward pressure on the wages of low- and medium-skilled workers employed in developed countries (results in columns 1 and 3). This negative impact of foreign sourcing is also sustained when $O F F$ is decomposed (a negative and statistically significant parameter for IntOUT is reported in columns 2 and 4). Again the magnitude of the parameters are relatively low, with elasticises both for low and medium-skilled workers lower than 10.1I. There is no effect on high skilled workers in developed countries.

\footnotetext{
31 The share of developed countries (as destination countries) in the overall imported inputs from all 40 source countries is $77 \%$ in 2009 (for comparison, $88 \%$ in 1995). Taking into account only imports from developing countries, in $200977 \%$ were also sent to developed countries (92\% in 1995). Own calculations, based on data from WIOD, industries and countries listed in Tables 9 and 10 respectively.

32 We also run all the estimates for the subsample of developing countries. However, in none of the specifications are offshoring indices among the statistically significant parameters. Results obtainable upon request.
} 


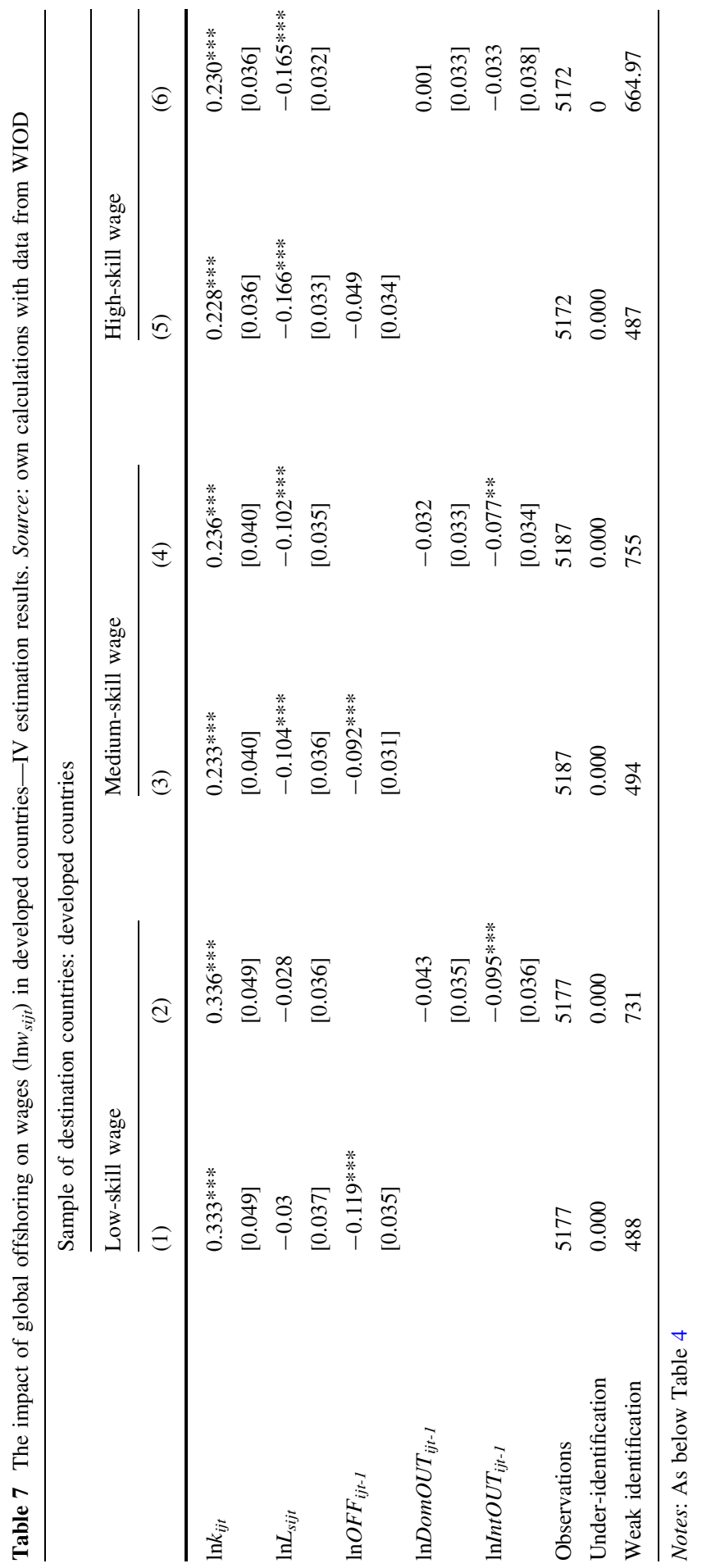


Table 8 The impact of offshoring on wages of low-skilled workers $\left(\ln w_{s i j t}\right)$ in developed countries-IV estimation, source countries split into low-wage and high-wage countries (LWC and HWC). Source: own calculations with data from WIOD

\begin{tabular}{|c|c|c|c|c|}
\hline & \multicolumn{4}{|c|}{ Sample of destination countries: developed countries } \\
\hline & $\begin{array}{l}\text { LWC class. } 1 \\
\text { (1) }\end{array}$ & $\begin{array}{l}\text { LWC class. } 2 \\
\text { (2) }\end{array}$ & $\begin{array}{l}\text { LWC class. } 3 \\
\text { (3) }\end{array}$ & $\begin{array}{l}\text { LWC class. } 4 \\
\text { (4) }\end{array}$ \\
\hline \multirow[t]{2}{*}{$1 n k_{i j t}$} & $0.284 * * *$ & $0.296 * * *$ & $0.301 * * *$ & $0.323 * * *$ \\
\hline & [0.041] & [0.043] & [0.044] & {$[0.047]$} \\
\hline \multirow[t]{2}{*}{$\ln L_{s i j t}$} & $-0.081 * *$ & $-0.062 *$ & $-0.058 *$ & -0.037 \\
\hline & {$[0.033]$} & {$[0.034]$} & {$[0.035]$} & {$[0.036]$} \\
\hline \multirow[t]{2}{*}{$\ln$ DomOUT $T_{i j t-1}$} & $-0.072 *$ & $-0.077 * *$ & $-0.074 * *$ & $-0.073 *$ \\
\hline & [0.037] & {$[0.037]$} & {$[0.038]$} & [0.038] \\
\hline \multirow[t]{2}{*}{$\ln I n t O U T_{-} L W C_{i j t-1}$} & $-0.103^{* * *}$ & $-0.099 * * *$ & $-0.100^{* * *}$ & $-0.095^{* * *}$ \\
\hline & {$[0.012]$} & {$[0.014]$} & {$[0.016]$} & {$[0.019]$} \\
\hline \multirow[t]{2}{*}{$\ln I n t O U T \_H W C_{i j t-1}$} & -0.055 & -0.064 & -0.045 & -0.048 \\
\hline & [0.034] & {$[0.054]$} & [0.039] & [0.038] \\
\hline Observations & 5177 & 5177 & 5177 & 5177 \\
\hline Under-identification & 0.000 & 0.000 & 0.000 & 0.000 \\
\hline Weak identification & 118 & 123 & 148 & 106 \\
\hline
\end{tabular}

Notes: As below Table 5

The next step is to explicitly assess the role of offshoring to LWC on the wages of low-skilled workers employed in developed countries. As Table 8 shows, after separating the role of domestic sourcing, the parameter associated with international offshoring to LWC (IntOUT_LWC) turns out to be negative and statistically significant, but small. Alternative LWC classifications do not significantly alter this result.

\subsection{Alternative specifications and robustness checks}

In this study, we are primarily interested in the effect of offshoring on domestic wages. Hence, our baseline specification (3) assumes that the main channel of the offshoring impact on the labour market is through wage adjustment. In the model we observe this outcome (wages) only for the employed. However, we are aware that there are other channels to be considered. First of all, and especially if wages are rigid, the adjustment of domestic labour markets to the movement of some parts of production abroad can materialize through a drop in employment. ${ }^{33}$ Autor et al.

\footnotetext{
33 This issue is also linked to the time of labour markets' response to offshoring. Short term wage effects arise when workers are immobile across countries and industries; while in the long run worker and firm mobility is more probable, so the adjustment can also pass through employment. Theoretical mechanisms of short and long run effects of increased fragmentation and offshoring on wages can be found in Rodríguez-Clare's (2010) Ricardian model. Their short-run analysis shows that when fragmentation is sufficiently high, further increases in fragmentation lead to a deterioration (improvement) in the real wage in the rich (poor) country. In the long-run these effects may be reversed as countries adjust their research efforts in response to increased offshoring.
} 
(2013) argue that in such cases estimates of wage adjustment can be biased. Additionally, offshoring can impact domestic wages indirectly-through productivity changes (this argument is present in theoretical models of trade in tasks, such as Grossman and Rossi-Hansberg 2008), e.g. an increase in productivity due to global production sharing should raise wage levels. If offshoring really lowers employment and/or raises productivity, then the inclusion of labour and capital ${ }^{34}$ controls in the estimated wage regression eliminates important channels through which offshoring impacts wages. In the first robustness check we thus compare our baseline specification (in which we hold employment and capital fixed) with the model allowing employment and capital intensity to change in response to offshoring. ${ }^{35}$ The results are presented in Tables 14 and 15 (columns 1 and 2) in "Appendix". The modified model yields a very similar response of low and medium-skilled workers' wages to offshoring to LWC to that obtained when employment and capital are both controlled for. ${ }^{36}$

Our second robustness check is motivated by the fact that wage rigidity varies substantially across countries, due to the diversity of labour market institutions. So far, domestic labour market conditions and regulations have not been explicitly taken into account, as the set of dummies and fixed effects should have picked up the effects specific to single countries and industries. Nevertheless, we augment the baseline regression with some additional country-specific covariates, such as the unemployment rate $^{37}$ and the degree of wage-setting coordination. ${ }^{38}$ After controlling for diversity in labour market conditions in this way, the results (reported in Tables 15-columns 3 and 4 and in Table 16 in "Appendix") do not change dramatically: the negative effect of offshoring on domestic wages materializes through imports from LWC and concerns mainly low- and mediumskilled workers. As expected, unemployment negatively affects the wages of all the skills groups and the wage bargaining setting is important for the determination of wages. Assuming that centralized wage-bargaining systems are less flexible than decentralized ones, in countries with rigid wages offshoring should have stronger

\footnotetext{
34 We do not include an additional productivity measure, e.g. value added per hour worked, since its correlation with the capital-labour ratio is very high (the coefficient of correlation equals 0.87 ).

35 Hummels et al. (2014) propose a similar approach to distinguish between the direct and indirect effects of offshoring on wages. In their study, they possess data at the firm level and compare the estimates with and without firm controls.

36 We further check whether this result does not stem from the fact that the 'productivity effect' and the 'labour substitution effect' exhibit opposite impacts on wages and thus offset each other. However, this is not confirmed by a comparison of the point estimates from two regressions: one controlling only for employment (allowing for capital changes) and a second controlling only for capital (allowing for employment changes). Taking into account the results obtained with the baseline LWC classification 4, the point estimates of offshoring to LWC on low-skilled wages in these two models are equal to -0.098 and -0.085 , respectively.

37 Data from the World Bank.

38 The information comes from the database on Institutional Characteristics of Trade Unions, Wage Setting, State Intervention and Social Pacts, 1960-2011 (ICTWSS), constructed by Jelle Visser (version 4.0, April 2013). There is no data for MEX, RUS, TUR and TWN. Coordination of wage-setting is expressed as a number ranging between 1 (fragmented wage bargaining, confined largely to individual firms or plants) to 5 (centralized wage bargaining).
} 
effects on employment than on wages. ${ }^{39}$ Indeed, the magnitude of the estimated elasticity between wages and IntOUT and IntOUT_LWC is here lower $(-0.054$ for low-skilled and -0.036 for medium-skilled) than in the results reported in the main text (Tables 5 and 6).

A third robustness check considers sector heterogeneity. ${ }^{40}$ Our panel consists of 13 manufacturing sectors which differ in offshoring intensity and can differ in their reaction to its changes. The country-sector and sector-year individual effects incorporated in our baseline specification (Eq. 3) should have controlled for this. However, we do some additional robustness checks. In order to check whether the results are driven by any specific industry (note that manufacturing coke and petrol products has already been eliminated from the sample), we repeat all the estimates, eliminating each of our 13 sectors one by one and running the regression for the remaining 12. The results are very similar to the baseline ones. In particular, the point estimates obtained for the IntOUT_LWC variable (analogous to those in Table 5) are between -0.079 (when industry "Manufacturing not elsewhere classified; Recycling" is eliminated) to -0.097 (when "Electrical And Optical Equipment" is not taken into account). This exercise also addresses the problem of interpreting machinery intermediate imports as an offshoring practice, which is raised by some authors, ${ }^{41}$ since our results are robust to the exclusion of machinery imports from the sample (point estimate -0.083).

Next, in order to check the relationship between offshoring and the technological content of the activities of an industry (for example, Hertveldt and Michel 2013 argue that offshoring is less common for high-tech industries as it requires more sophisticated inputs), we test for differences between high-tech and low-tech industries. ${ }^{42}$ We introduce into the model an interaction term between offshoring and a high-tech industry dummy (or a term for interaction between offshoring to LWC/HWC and the high-tech dummy). Following Wooldridge (2010), we instrument this using an interaction between high-tech and our instruments for offshoring. Table 17 presents the results. Indeed, the wage drop due to offshoring is stronger for low-tech industries; for high-tech industries a positive and statistically significant coefficient on the interaction term suggests that the effect of offshoring on wages is weaker.

The final robustness check considers the possible interdependence of wages of different skill categories of workers. To take this issue into account, we estimated the model through three-stage least squares (3SLS) in which we combine the system estimation of SUR with the instrumental variables method of 2SLS (Zellner and Theil 1962). The results of this exercise are very similar to our baseline specification

\footnotetext{
39 As noted by Geishecker et al. (2010), the problem can be more complex. For example, it is possible that in countries with rigid wages (with a centralized wage bargaining system) which are at the same time characterized by low flexibility of employment (e.g. due to a high level of employment protection) offshoring impacts the labour market through wage adjustment rather than employment corrections.

40 The detailed results are available upon request.

41 For example, Hummels et al. (2014) argue that machinery imports may affect wages through access to foreign technology rather than through offshoring per se.

42 Our division between high- and low-tech manufacturing industries follows Foster-McGregor et al. (2013) and is reported in Table 9 in the "Appendix".
} 
as far as the significance of the parameters and their magnitude are considered (see Table 18 in "Appendix").

\section{Conclusions}

This paper extends the literature on the implications of offshoring for labour markets by investigating its effect on the wages of different skill groups in a broad global context. Outsourcing can be viewed as a specific facet of deepening trade integration, in particular the recent wave of globalisation and the so-called second unbundling (expression coined by Baldwin). The aim of our study is to test ambiguous effects of offshoring on wages in the presence of task relocation. Our analysis draws on input-output data from the WIOD project and in the panel analysed (13 manufacturing industries, 40 countries, 1995-2009) we have captured up to $96 \%$ of international trade in manufacturing inputs. Being particularly interested in the wage effects of offshoring to developing and low-wage countries (LWC), we employ novel, precise LWC classifications (varying across industries and time) to decompose global offshoring by source country.

Some shortcomings of this study need to be admitted, mainly regarding the specification of our offshoring measure, which is expressed as imported intermediate inputs. First, in order to guarantee that we consider the process of production fragmentation rather than purchasing natural resources we excluded raw materials from our industry sample. Second, the increased use of inputs (together with imported inputs) can be simply the consequence of production growth. We minimalized this problem by taking into account the size of the industry through an employment variable and a set of dummies, especially country-industry and industry-time. Third, it may be that offshoring is the result of domestic structural changes e.g. through substituting foreign inputs for inputs previously purchased from another domestic supplier. Since we are explicitly interested in the case when foreign inputs substitute inputs previously produced within the firm, we performed the decomposition ruling out domestic outsourcing. However, it should be noted that a limitation of our study (and other papers which use input-output tables to compute offshoring indices) is that we are unable to account for offshoring of final production stages or of products which are not re-imported but exported to third markets (Hijzen et al. 2005).

We find that the negative effect of offshoring on the domestic wages of low- and medium- skilled workers is connected with imports from low-wage countries, but in terms of magnitude this effect is rather small. The negative effect is not found for high-skilled workers. These results are confirmed in a number of robustness checks.

Our findings that domestic wages do not dramatically decrease due to offshoring is in line with the results of some other industry-level studies, such as Edwards and Lawrence (2010), Ebenstein et al. (2014), or Parteka and Wolszczak-Derlacz (2015). A possible explanation is that the downward pressure from offshoring is cancelled by increased productivity, which may raise wages. Autor et al. (2013) oppose the lack of significant effects of import exposure on manufacturing wages to the impact felt outside manufacturing sectors. Alternatively, Ebenstein et al. (2014) 
conclude that wage adjustment materializes not at the level of industries but at the level of occupations. However, due to the industry nature of our data we have not been able to address this issue. There is a trade-off between our extensive data coverage (40 countries, 13 manufacturing sectors) and the detail of micro-level information usually available for a limited number of countries. The link between offshoring and wages is of great importance for policy recommendations and hence needs to be analysed comprehensively both from macro- and micro-level perspectives.

Acknowledgments The research has been conducted within the project financed by the National Science Centre (NCN), Poland (decision number DEC-2013/11/B/HS4/02134). We would like to thank two anonymous referees, as well as the participants to the following conferences: Warsaw International Economic Meeting (University of Warsaw, 2015), Spanish Association of International Economics and Finance Conference (San Sebastian, 2015), ETSG 2015 (Paris, 2015) for valuable comments and suggestions.

Open Access This article is distributed under the terms of the Creative Commons Attribution 4.0 International License (http://creativecommons.org/licenses/by/4.0/), which permits unrestricted use, distribution, and reproduction in any medium, provided you give appropriate credit to the original author(s) and the source, provide a link to the Creative Commons license, and indicate if changes were made.

\section{Appendix}

See Tables 9, 10, 11, 12, 13, 14, 15, 16, 17 and 18 .

Table 9 List of manufacturing industries

\begin{tabular}{lll}
\hline Industry code & Description & Industry type \\
\hline $15 \mathrm{t} 16$ & Food, Beverages and Tobacco & Low-tech \\
$17 \mathrm{t} 18$ & Textiles and Textile Products & Low-tech \\
19 & Leather, Leather and Footwear & Low-tech \\
20 & Wood and Products of Wood and Cork & Low-tech \\
$21 \mathrm{t} 22$ & Pulp, Paper, Printing and Publishing & Medium-tech \\
24 & Chemicals and Chemical Products & High tech \\
25 & Rubber And Plastics & Medium tech \\
26 & Other Non-Metallic Mineral Products & Low tech \\
$27 \mathrm{t} 28$ & Basic Metals and Fabricated Metal & Low tech \\
29 & Machinery not elsewhere classified & High tech \\
$30 \mathrm{t} 33$ & Electrical and Optical Equipment & High tech \\
$34 \mathrm{t} 35$ & Transport Equipment & High tech \\
$36 \mathrm{t} 37$ & Manufacturing not elsewhere classified; Recycling & Medium tech
\end{tabular}

Notes: Division into high-, medium- and low-tech manufacturing according to Foster-McGregor et al. (2013) 
Table 10 List of countries and division between developed and developing countries

\begin{tabular}{|c|c|c|}
\hline Country code & Country name & $=1$ if developing \\
\hline AUS & Australia & 0 \\
\hline AUT & Austria & 0 \\
\hline BEL & Belgium & 0 \\
\hline BGR & Bulgaria & 1 \\
\hline BRA & Brazil & 1 \\
\hline CAN & Canada & 0 \\
\hline $\mathrm{CHN}$ & China & 1 \\
\hline CYP & Cyprus & 0 \\
\hline $\mathrm{CZE}$ & Czech Republic & 0 \\
\hline $\mathrm{DEU}$ & Germany & 0 \\
\hline DNK & Denmark & 0 \\
\hline ESP & Spain & 0 \\
\hline EST & Estonia & 0 \\
\hline FIN & Finland & 0 \\
\hline FRA & France & 0 \\
\hline GBR & United Kingdom & 0 \\
\hline GRC & Greece & 0 \\
\hline HUN & Hungary & 1 \\
\hline IDN & India & 1 \\
\hline IND & Indonesia & 1 \\
\hline IRL & Ireland & 0 \\
\hline ITA & Italy & 0 \\
\hline JPN & Japan & 0 \\
\hline KOR & Korea & 0 \\
\hline LTU & Lithuania & 0 \\
\hline LUX & Luxembourg & 0 \\
\hline LVA & Latvia & 0 \\
\hline MEX & Mexico & 1 \\
\hline MLT & Malta & 0 \\
\hline NLD & Netherlands & 0 \\
\hline POL & Poland & 0 \\
\hline PRT & Portugal & 0 \\
\hline ROM & Romania & 1 \\
\hline RUS & Russia & 0 \\
\hline SVK & Slovak Republic & 0 \\
\hline SVN & Slovenia & 0 \\
\hline SWE & Sweden & 0 \\
\hline TUR & Turkey & 1 \\
\hline TWN & Taiwan & 0 \\
\hline USA & United States of America & 0 \\
\hline
\end{tabular}

Notes: Developing countries defined as low- and middle-income countries according to the World Bank, 2014 
Table 11 Countries classified as low-wage according to classification 4 (2009)

\begin{tabular}{|c|c|c|c|c|c|c|c|c|c|c|c|c|c|}
\hline Industry code & $15 \mathrm{t} 16$ & $17 \mathrm{t} 18$ & 19 & 20 & $21 \mathrm{t} 22$ & 24 & 25 & 26 & $27 \mathrm{t} 28$ & 29 & $30 \mathrm{t} 33$ & $34 \mathrm{t} 35$ & $36 \mathrm{t} 37$ \\
\hline AUS & 0 & 0 & 0 & 0 & 0 & 0 & 0 & 0 & 0 & 0 & 0 & 0 & 0 \\
\hline AUT & 0 & 0 & 0 & 0 & 0 & 0 & 0 & 0 & 0 & 0 & 0 & 0 & 0 \\
\hline BEL & 0 & 0 & 0 & 0 & 0 & 0 & 0 & 0 & 0 & 0 & 0 & 0 & 0 \\
\hline BGR & $\mathrm{X}$ & $\mathrm{X}$ & $X$ & $X$ & $\mathrm{X}$ & $X$ & $\mathrm{X}$ & $X$ & $\mathrm{X}$ & $\mathrm{X}$ & $\mathrm{X}$ & $\mathrm{X}$ & $\mathrm{X}$ \\
\hline BRA & $X$ & $X$ & $X$ & $X$ & $X$ & 0 & $X$ & $X$ & $X$ & 0 & 0 & 0 & $X$ \\
\hline CAN & 0 & 0 & 0 & 0 & 0 & 0 & 0 & 0 & 0 & 0 & 0 & 0 & 0 \\
\hline $\mathrm{CHN}$ & $\mathrm{X}$ & $X$ & $X$ & $\mathrm{X}$ & $\mathrm{X}$ & $\mathrm{X}$ & $\mathrm{X}$ & $X$ & $X$ & $\mathrm{X}$ & $\mathrm{X}$ & $\mathrm{X}$ & $\mathrm{X}$ \\
\hline CYP & 0 & 0 & 0 & 0 & 0 & 0 & 0 & 0 & 0 & 0 & 0 & 0 & 0 \\
\hline CZE & 0 & 0 & 0 & 0 & 0 & 0 & 0 & 0 & 0 & 0 & 0 & 0 & 0 \\
\hline DEU & 0 & 0 & 0 & 0 & 0 & 0 & 0 & 0 & 0 & 0 & 0 & 0 & 0 \\
\hline DNK & 0 & 0 & 0 & 0 & 0 & 0 & 0 & 0 & 0 & 0 & 0 & 0 & 0 \\
\hline ESP & 0 & 0 & 0 & 0 & 0 & 0 & 0 & 0 & 0 & 0 & 0 & 0 & 0 \\
\hline EST & 0 & 0 & 0 & 0 & 0 & $\mathrm{X}$ & 0 & 0 & 0 & 0 & 0 & 0 & 0 \\
\hline FIN & 0 & 0 & 0 & 0 & 0 & 0 & 0 & 0 & 0 & 0 & 0 & 0 & 0 \\
\hline FRA & 0 & 0 & 0 & 0 & 0 & 0 & 0 & 0 & 0 & 0 & 0 & 0 & 0 \\
\hline GBR & 0 & 0 & 0 & 0 & 0 & 0 & 0 & 0 & 0 & 0 & 0 & 0 & 0 \\
\hline GRC & 0 & 0 & 0 & 0 & 0 & 0 & 0 & 0 & 0 & 0 & 0 & 0 & 0 \\
\hline HUN & $X$ & $X$ & 0 & $X$ & 0 & 0 & 0 & 0 & 0 & 0 & 0 & 0 & $X$ \\
\hline IDN & $X$ & $X$ & $X$ & $X$ & $X$ & 0 & $X$ & $X$ & $\mathrm{X}$ & 0 & 0 & 0 & $X$ \\
\hline IND & $\mathrm{X}$ & $\mathrm{X}$ & $X$ & $\mathrm{X}$ & $\mathrm{X}$ & $X$ & $X$ & $X$ & $\mathrm{X}$ & $X$ & $\mathrm{X}$ & $\mathrm{X}$ & $X$ \\
\hline IRL & 0 & 0 & 0 & 0 & 0 & 0 & 0 & 0 & 0 & 0 & 0 & 0 & 0 \\
\hline ITA & 0 & 0 & 0 & 0 & 0 & 0 & 0 & 0 & 0 & 0 & 0 & 0 & 0 \\
\hline JPN & 0 & 0 & 0 & 0 & 0 & 0 & 0 & 0 & 0 & 0 & 0 & 0 & 0 \\
\hline KOR & 0 & 0 & 0 & 0 & 0 & 0 & 0 & 0 & 0 & 0 & 0 & 0 & 0 \\
\hline LTU & 0 & $\mathrm{X}$ & $X$ & $X$ & 0 & $X$ & $X$ & $X$ & $X$ & 0 & 0 & $\mathrm{X}$ & 0 \\
\hline LUX & 0 & 0 & & 0 & 0 & 0 & 0 & 0 & 0 & 0 & 0 & 0 & 0 \\
\hline LVA & $X$ & $X$ & $X$ & $X$ & 0 & $\mathrm{X}$ & 0 & 0 & 0 & $\mathrm{X}$ & $X$ & $X$ & $X$ \\
\hline MEX & $X$ & $X$ & $X$ & $X$ & $X$ & $X$ & $X$ & $X$ & $X$ & $\mathrm{X}$ & $X$ & $X$ & $X$ \\
\hline MLT & 0 & 0 & 0 & 0 & 0 & $X$ & 0 & 0 & 0 & 0 & 0 & 0 & 0 \\
\hline NLD & 0 & 0 & 0 & 0 & 0 & 0 & 0 & 0 & 0 & 0 & 0 & 0 & 0 \\
\hline POL & 0 & $X$ & $X$ & $X$ & 0 & 0 & 0 & 0 & 0 & 0 & 0 & $X$ & $X$ \\
\hline PRT & 0 & 0 & 0 & 0 & 0 & 0 & 0 & 0 & 0 & 0 & 0 & 0 & 0 \\
\hline ROU & 0 & $\mathrm{X}$ & $X$ & $X$ & $\mathrm{X}$ & 0 & $X$ & 0 & $X$ & $\mathrm{X}$ & $X$ & $X$ & $X$ \\
\hline RUS & $X$ & $X$ & $X$ & $\mathrm{X}$ & $X$ & $\mathrm{X}$ & $X$ & $X$ & $X$ & $\mathrm{X}$ & $X$ & $\mathrm{X}$ & $X$ \\
\hline SVK & $X$ & $\mathrm{X}$ & $X$ & $X$ & 0 & $X$ & 0 & 0 & 0 & $\mathrm{X}$ & $X$ & $\mathrm{X}$ & 0 \\
\hline SVN & 0 & 0 & 0 & 0 & 0 & 0 & 0 & 0 & 0 & 0 & 0 & 0 & 0 \\
\hline SWE & 0 & 0 & & 0 & 0 & 0 & 0 & 0 & 0 & 0 & 0 & 0 & 0 \\
\hline TUR & $X$ & $X$ & $X$ & $X$ & 0 & 0 & $X$ & $X$ & $X$ & $X$ & $X$ & $X$ & $X$ \\
\hline
\end{tabular}


Table 11 continued

\begin{tabular}{llllllllllllll}
\hline Industry code & $15 \mathrm{t} 16$ & $17 \mathrm{t} 18$ & 19 & 20 & $21 \mathrm{t} 22$ & 24 & 25 & 26 & $27 \mathrm{t} 28$ & 29 & $30 \mathrm{t} 33$ & $34 \mathrm{t} 35$ & $36 \mathrm{t} 37$ \\
\hline TWN & 0 & 0 & $\mathrm{X}$ & $\mathrm{X}$ & $\mathrm{X}$ & 0 & 0 & $\mathrm{X}$ & 0 & 0 & $\mathrm{X}$ & $\mathrm{X}$ & $\mathrm{X}$ \\
USA & 0 & 0 & 0 & 0 & 0 & 0 & 0 & 0 & 0 & 0 & 0 & 0 & 0
\end{tabular}

Notes: X means the given country is classified as LWC (according to classification 4 based on comparison of wages paid within industries, threshold: $30 \%$ ). Industries in separate columns. Complete classification tables (for all countries, sectors and years) is available as additional supplementary material (online)

Table 12 Endogeneity tests

\begin{tabular}{lllll}
\hline & $\ln L_{i j t}$ & $\ln$ OFF & & \\
\hline Test stat $\left[\chi^{2}(1)\right]$ & 1.132 & 7.968 & $\ln$ DomOUT $_{i j t}$ & $\ln$ IntOUT \\
$p$ value & 0.287 & 0.005 & 0.010 & 5.312 \\
\hline
\end{tabular}

Notes: GMM distance test based on 1-year lag of: $\ln L_{i j t}, \ln D o m O U T_{i j t}$ and gravity instrument of: $\ln O F F_{i j t}$ and $\ln I n t O U T_{i j t}$. H0: the regressor can be treated as exogenous; computed with xtivreg2 in STATA. Results of the tests when the regressors are offshoring indices to specific regions: LWC and HWC are available upon request

Table 13 The impact of offshoring on wages of high-skilled workers $\left(\ln w_{s i j t}\right)$-IV estimation, source countries split into low-wage and high-wage countries (LWC and HWC). Source: own calculations with data from WIOD

\begin{tabular}{|c|c|c|c|c|}
\hline & \multicolumn{4}{|c|}{ Sample: all destination countries (40) } \\
\hline & $\begin{array}{l}\text { LWC class. } 1 \\
\text { (2) }\end{array}$ & $\begin{array}{l}\text { LWC class. } 2 \\
\text { (3) }\end{array}$ & $\begin{array}{l}\text { LWC class. } 3 \\
\text { (4) }\end{array}$ & $\begin{array}{l}\text { LWC class. } 4 \\
\text { (5) }\end{array}$ \\
\hline \multirow[t]{2}{*}{$1 n k_{i j t}$} & $0.303 * * *$ & $0.311 * * *$ & $0.311 * * *$ & $0.313 * * *$ \\
\hline & {$[0.037]$} & {$[0.038]$} & {$[0.038]$} & {$[0.038]$} \\
\hline \multirow[t]{2}{*}{$\ln L_{s i j t}$} & $-0.197 * * *$ & $-0.188 * * *$ & $-0.189 * * *$ & $-0.188 * * *$ \\
\hline & [0.032] & [0.032] & {$[0.032]$} & [0.032] \\
\hline \multirow[t]{2}{*}{$\ln$ DomOUT $_{i j t-1}$} & -0.023 & -0.028 & -0.016 & -0.013 \\
\hline & {$[0.033]$} & {$[0.033]$} & {$[0.033]$} & {$[0.033]$} \\
\hline \multirow[t]{2}{*}{$\ln I n t O U T \_L W C_{i j t-1}$} & $-0.034 * * *$ & -0.017 & -0.014 & -0.026 \\
\hline & [0.011] & [0.012] & [0.014] & {$[0.017]$} \\
\hline \multirow[t]{2}{*}{$\ln I n t O U T \_H W C_{i j t-1}$} & -0.041 & -0.065 & -0.044 & -0.032 \\
\hline & {$[0.031]$} & {$[0.051]$} & {$[0.034]$} & {$[0.032]$} \\
\hline Observations & 6687 & 6687 & 6687 & 6687 \\
\hline Under-identification & 0.000 & 0.000 & 0.000 & 0.000 \\
\hline Weak identification & 147 & 162 & 165 & 133 \\
\hline
\end{tabular}

Notes: As below Table 5 
Table 14 Robustness check: the impact of global offshoring on wages $\left(\ln w_{s i j t}\right)$-IV estimation, specification without labour or capital controls. Source: own calculations with data from WIOD

\begin{tabular}{|c|c|c|c|c|c|c|}
\hline & \multicolumn{6}{|c|}{ Sample: all destination countries (40) } \\
\hline & \multicolumn{2}{|c|}{ Low-skill wage } & \multicolumn{2}{|c|}{ Medium-skill wage } & \multicolumn{2}{|c|}{ High-skill wage } \\
\hline & (1) & (2) & (3) & (4) & $(5)$ & (6) \\
\hline \multirow[t]{2}{*}{$\ln O F F_{i j t-1}$} & $-0.112 * * *$ & & $-0.104 * * *$ & & -0.064 & \\
\hline & {$[0.034]$} & & {$[0.032]$} & & {$[0.056]$} & \\
\hline \multirow[t]{2}{*}{$\ln D o m O U T_{i j t-1}$} & & -0.046 & & -0.041 & & -0.005 \\
\hline & & {$[0.038]$} & & {$[0.036]$} & & {$[0.038]$} \\
\hline \multirow[t]{2}{*}{$\ln I n t O U T_{i j t-1}$} & & -0.051 & & -0.04 & & 0.001 \\
\hline & & {$[0.036]$} & & {$[0.036]$} & & {$[0.039]$} \\
\hline Observations & 6693 & 6693 & 6703 & 6703 & 6688 & 6688 \\
\hline Under-identification & 0.000 & 0.000 & 0.000 & 0.000 & 0.000 & 0.000 \\
\hline Weak identification & 774.3 & 724.5 & 778 & 721.3 & 771 & 690.2 \\
\hline
\end{tabular}

Notes: As below Table 4

Table 15 Robustness check: the impact of offshoring on wages of low and medium-skilled workers. Specification without labour and capital controls (columns 1 and 2); specification with additional variables (columns 3 and 4). Source: own calculations with data from WIOD, UN from World Bank, and Coord from ICTWSS

\begin{tabular}{|c|c|c|c|c|}
\hline & \multicolumn{2}{|c|}{$\begin{array}{l}\text { Specification without labour and capital } \\
\text { controls }\end{array}$} & \multicolumn{2}{|c|}{$\begin{array}{l}\text { Specification with additional control } \\
\text { variables }\end{array}$} \\
\hline & $\begin{array}{l}\text { Low-skilled wage } \\
\text { (1) }\end{array}$ & $\begin{array}{l}\text { Medium-skilled wage } \\
\text { (2) }\end{array}$ & $\begin{array}{l}\text { Low-skilled wage } \\
\text { (3) }\end{array}$ & $\begin{array}{l}\text { Medium-skilled } \\
\text { wage } \\
\text { (4) }\end{array}$ \\
\hline $\ln D o m O U T_{i j t-1}$ & $\begin{array}{l}-0.089 * * \\
{[0.039]}\end{array}$ & $\begin{array}{l}-0.075^{* *} \\
{[0.037]}\end{array}$ & $\begin{array}{l}-0.012 * * * \\
{[0.002]}\end{array}$ & $\begin{array}{l}-0.061^{*} \\
{[0.031]}\end{array}$ \\
\hline $\ln I n t O U T \_L W C_{i j t-1}$ & $\begin{array}{l}-0.107 * * * \\
{[0.021]}\end{array}$ & $\begin{array}{l}-0.084 * * * \\
{[0.020]}\end{array}$ & $\begin{array}{l}-0.054 * * * \\
{[0.018]}\end{array}$ & $\begin{array}{l}-0.036^{* *} \\
{[0.016]}\end{array}$ \\
\hline $\ln I n t O U T \_H W C_{i j t-1}$ & $\begin{array}{l}-0.008 \\
{[0.038]}\end{array}$ & $\begin{array}{l}-0.018 \\
{[0.036]}\end{array}$ & $\begin{array}{l}-0.013 \\
{[0.037]}\end{array}$ & $\begin{array}{l}-0.036 \\
{[0.035]}\end{array}$ \\
\hline $\ln k_{i j t}$ & & & $\begin{array}{l}0.399 * * * \\
{[0.047]}\end{array}$ & $\begin{array}{l}0.324 * * * \\
{[0.043]}\end{array}$ \\
\hline $\ln L_{s i j t}$ & & & $\begin{array}{l}-0.061 * \\
{[0.035]}\end{array}$ & $\begin{array}{l}-0.117 * * * \\
{[0.037]}\end{array}$ \\
\hline$U N_{\text {it }}$ & & & $\begin{array}{l}-0.071^{* *} \\
{[0.033]}\end{array}$ & $\begin{array}{l}-0.012 * * * \\
{[0.002]}\end{array}$ \\
\hline Coord $_{\mathrm{it}}$ & & & $\begin{array}{l}0.013 * * * \\
{[0.005]}\end{array}$ & $\begin{array}{l}0.008 * \\
{[0.004]}\end{array}$ \\
\hline
\end{tabular}


Table 15 continued

Specification without labour and capital
controls $\overline{\text { Low-skilled wage } \text { Medium-skilled wage }}$

(1)

\begin{tabular}{lllll}
\hline Observations & 6693 & 6703 & 5692 & 5702 \\
Under-identification & 0.000 & 0.000 & 0.000 & 0.000 \\
Weak identification & 139 & 144 & 118 & 128 \\
\hline
\end{tabular}

Notes: Columns 1 and 2 : notes as below Table 4, specification without labour and capital controls. Columns 3 and 4-notes as below Table 5, countries split into low-wage (LWC) and high-wage (HWC) according to classification (4), additional variables: unemployment rate $(U N)$, degree of wage-setting coordination (Coord)

Table 16 Robustness check: the impact of global offshoring on wages $\left(\ln w_{s i j t}\right)$-additional variables: unemployment rate $(U N)$, degree of wage-setting coordination (Coord). Source: Own calculations with data from WIOD, $U N$ from World Bank, and Coord from ICTWSS

\begin{tabular}{|c|c|c|c|c|c|c|}
\hline & \multicolumn{6}{|c|}{ Sample: all countries (40) } \\
\hline & \multicolumn{2}{|c|}{ Low-skill wage } & \multicolumn{2}{|c|}{ Medium-skill wage } & \multicolumn{2}{|c|}{ High-skill wage } \\
\hline & (1) & (2) & (3) & (4) & (5) & (6) \\
\hline $\ln k_{i j t}$ & $\begin{array}{l}0.407 * * * \\
{[0.047]}\end{array}$ & $\begin{array}{l}0.407 * * * \\
{[0.048]}\end{array}$ & $\begin{array}{l}0.329 * * * \\
{[0.043]}\end{array}$ & $\begin{array}{l}0.330 * * * \\
{[0.043]}\end{array}$ & $\begin{array}{l}0.304 * * * \\
{[0.041]}\end{array}$ & $\begin{array}{l}0.304 * * * \\
{[0.041]}\end{array}$ \\
\hline $\ln L_{s i j t}$ & $\begin{array}{l}-0.056 \\
{[0.036]}\end{array}$ & $\begin{array}{l}-0.056 \\
{[0.035]}\end{array}$ & $\begin{array}{l}-0.115^{* * *} \\
{[0.037]}\end{array}$ & $\begin{array}{l}-0.114 * * * \\
{[0.036]}\end{array}$ & $\begin{array}{l}-0.182 * * * \\
{[0.032]}\end{array}$ & $\begin{array}{l}-0.183 * * * \\
{[0.031]}\end{array}$ \\
\hline$U N_{\text {it }}$ & $\begin{array}{l}-0.012 * * * \\
{[0.002]}\end{array}$ & $\begin{array}{l}-0.012^{* * * *} \\
{[0.002]}\end{array}$ & $\begin{array}{l}-0.012^{* * *} \\
{[0.002]}\end{array}$ & $\begin{array}{l}-0.012 * * * \\
{[0.002]}\end{array}$ & $\begin{array}{l}-0.006^{* * *} \\
{[0.002]}\end{array}$ & $\begin{array}{l}-0.006 * * * \\
{[0.002]}\end{array}$ \\
\hline $\operatorname{Coord}_{\text {it }}$ & $\begin{array}{l}0.015 * * * \\
{[0.005]}\end{array}$ & $\begin{array}{l}0.015 * * * \\
{[0.005]}\end{array}$ & $\begin{array}{l}0.009 * * \\
{[0.004]}\end{array}$ & $\begin{array}{l}0.009 * * \\
{[0.004]}\end{array}$ & $\begin{array}{l}0.010^{*} \\
{[0.005]}\end{array}$ & $\begin{array}{l}0.010^{*} \\
{[0.005]}\end{array}$ \\
\hline $\ln O F F_{i j t-1}$ & $\begin{array}{l}-0.083^{* *} \\
{[0.036]}\end{array}$ & & $\begin{array}{l}-0.066^{*} \\
{[0.034]}\end{array}$ & & $\begin{array}{l}-0.021 \\
{[0.036]}\end{array}$ & \\
\hline $\ln$ DomOUT $_{i j t-1}$ & & $\begin{array}{l}-0.044 \\
{[0.040]}\end{array}$ & & $\begin{array}{l}-0.042 \\
{[0.038]}\end{array}$ & & $\begin{array}{l}0.006 \\
{[0.040]}\end{array}$ \\
\hline $\ln I n t O U T_{i j t-1}$ & & $\begin{array}{l}-0.054^{*} \\
{[0.029]}\end{array}$ & & $\begin{array}{l}-0.04 \\
{[0.027]}\end{array}$ & & $\begin{array}{l}0.009 \\
{[0.028]}\end{array}$ \\
\hline Observations & 5692 & 5692 & 5702 & 5702 & 5690 & 5690 \\
\hline Under-identification & 0.000 & 0.000 & 0.000 & 0.000 & 0.000 & 0.000 \\
\hline Weak identification & 568.4 & 532 & 575.8 & 551 & 567.9 & 523 \\
\hline
\end{tabular}

Notes: As below Table 4. IV estimation, source countries split into low-wage and high-wage countries (LWC and HWC) 
Table 17 Robustness check: sector heterogeneity (high-tech versus low-tech industries). Source: Own calculations with data from WIOD

\begin{tabular}{|c|c|c|c|}
\hline & $\begin{array}{l}\text { Low-skilled wage } \\
\text { (1) }\end{array}$ & $\begin{array}{l}\text { Medium-skilled wage } \\
\text { (2) }\end{array}$ & $\begin{array}{l}\text { High-skilled wage } \\
\text { (3) }\end{array}$ \\
\hline \multirow[t]{2}{*}{$\ln k_{i j t}$} & $0.370 * * *$ & $0.292 * * *$ & $0.302 * * *$ \\
\hline & {$[0.042]$} & {$[0.037]$} & {$[0.037]$} \\
\hline \multirow[t]{2}{*}{$\ln L_{\text {sijt }}$} & $-0.094 * * *$ & $-0.182 * * *$ & $-0.198 * * *$ \\
\hline & {$[0.034]$} & {$[0.032]$} & {$[0.032]$} \\
\hline \multirow[t]{2}{*}{$\ln \operatorname{DomOUT}_{i j t-1}$} & $-0.074 * *$ & $-0.059^{*}$ & -0.029 \\
\hline & {$[0.033]$} & {$[0.031]$} & {$[0.034]$} \\
\hline \multirow[t]{2}{*}{$\ln I n t O U T \_L W C_{i j t-1}$} & $-0.132 * * *$ & $-0.124 * * *$ & $-0.074 * * *$ \\
\hline & {$[0.025]$} & {$[0.023]$} & {$[0.024]$} \\
\hline \multirow[t]{2}{*}{$\mathrm{HT} \times \ln I n t O U T \_L W C_{i j t-1}$} & $0.094 * * *$ & $0.109 * * *$ & $0.082 * *$ \\
\hline & {$[0.034]$} & {$[0.032]$} & {$[0.033]$} \\
\hline \multirow[t]{2}{*}{$\ln I n t O U T \_H W C_{i j t-1}$} & 0.013 & 0.007 & -0.001 \\
\hline & {$[0.046]$} & {$[0.042]$} & {$[0.044]$} \\
\hline \multirow[t]{2}{*}{$\mathrm{HT} \times \ln I n t O U T_{-} H W C_{i j t-1}$} & -0.036 & -0.073 & -0.096 \\
\hline & {$[0.087]$} & {$[0.084]$} & {$[0.090]$} \\
\hline Observations & 6692 & 6702 & 6687 \\
\hline Under-identification & 0.000 & 0.000 & 0.000 \\
\hline Weak identification & 17 & 17 & 17 \\
\hline
\end{tabular}

Notes: As below Table 5. IV estimation, model includes an additional interaction term between high-tech industry dummy, HT, and offshoring. Classification (4) of LWC, division of industries into high tech and low tech as in Table 9

Table 18 Robustness check: three-stage least squares SUR regression. Source: own calculations with data from WIOD

\begin{tabular}{|c|c|c|c|c|}
\hline & \multicolumn{4}{|c|}{ Sample: all countries (40) } \\
\hline & Low-skill wage & Medium-skill wage & Low-skill wage & Medium-skill wage \\
\hline \multirow[t]{2}{*}{$\ln k_{i j t}$} & $0.414 * * *$ & $0.353 * * *$ & $0.403 * * *$ & $0.345^{* * *}$ \\
\hline & {$[0.010]$} & {$[0.010]$} & {$[0.010]$} & [0.009] \\
\hline \multirow[t]{2}{*}{$\ln L_{i j t}$} & $-0.052^{* * *}$ & $-0.093 * * *$ & $-0.054 * * *$ & $-0.095^{* * *}$ \\
\hline & {$[0.006]$} & {$[0.005]$} & {$[0.005]$} & {$[0.005]$} \\
\hline \multirow[t]{2}{*}{$\ln \operatorname{DomOUT}_{i j t-1}$} & $-0.040 * * *$ & $-0.023 *$ & $-0.062 * * *$ & $-0.046 * * *$ \\
\hline & [0.013] & {$[0.012]$} & {$[0.015]$} & {$[0.014]$} \\
\hline \multirow[t]{2}{*}{$\ln I n t O U T_{i j t-1}$} & $-0.060 * * *$ & $-0.057 * * *$ & & \\
\hline & {$[0.015]$} & {$[0.014]$} & & \\
\hline \multirow[t]{2}{*}{$\ln I n t O U T \_L W C_{i j t-1}$} & & & $-0.087 * * *$ & $-0.069 * * *$ \\
\hline & & & {$[0.007]$} & {$[0.007]$} \\
\hline \multirow[t]{2}{*}{$\ln I n t O U T \_H W C_{i j t-1}$} & & & -0.007 & -0.023 \\
\hline & & & [0.015] & [0.014] \\
\hline
\end{tabular}


Table 18 continued

\begin{tabular}{lllll}
\hline & \multicolumn{2}{l}{ Sample: all countries (40) } & \\
\cline { 2 - 5 } & Low-skill wage & Medium-skill wage & Low-skill wage & Medium-skill wage \\
\hline Observations & 6671 & 6671 & 6671 & 6671 \\
\hline
\end{tabular}

Notes: Statistically significant at $* * * 1, * * 5, * 10$ percent level. In all specifications, year dummies, country-industry and country-year dummies included. Estimates obtained through three-stage least squares SUR regression with simultaneous estimates for low, medium and high-skilled wages. For highskilled wages in none of the specifications are offshoring indices among the statistically significant parameters. Results obtainable upon request. International outsourcing ( $\ln I n t O U T_{i j t}, \ln I n t O U T_{-} L W C_{i j t}$ and $\ln I n t O U T_{\_} H W C_{i j t}$ ) treated as endogenous variables and instrumented on the basis of the gravity equation as explained in the main text. Countries split into low-wage (LWC) and high-wage (HWC) according to the classification (4)

\section{References}

Acemoglu D, Autor DH (2011) Skills, tasks and technologies: implications for employment and earnings. In: Ashenfelter O, Card DE (eds) Handbook of labor economics, vol 4. Elsevier, Amsterdam, pp 1043-1171

Acemoglu D, Dorn D, Hanson GH, Price B (2014) Import competition and the Great US Employment Sag of the 2000 s, NBER Working Paper No. 20395

Acemoglu D, Gancia G, Zilibotti F (2015) Offshoring and directed technical change. Am Econ J: Macroecon, Am Econ Assoc 7(3):84-122

Amiti M, Wei SJ (2005) Fear of service outsourcing: is it justified? Econ policy 20(42):308-347

Autor DH (2013) The" task approach" to labor markets: an overview. J Labour Mark Res 46(3):185-199

Autor DH (2015) Why are there still so many jobs? The history and future of workplace automation. J Econ Perspect 29(3):3-30

Autor DH, Dorn D (2013) The growth of low-skill service jobs and the polarization of the US labor market. Am Econ Rev 103(5):1553-1597

Autor DH, Dorn D, Hanson GH (2013) The China syndrome: local labor market effects of import competition in the United States. Am Econ Rev 103(6):2121-2168

Autor DH, Dorn D, Hanson GH, Song J (2014) Trade adjustment: worker-level evidence. Q J Econ 129(4):1799-1860

Autor DH, Dorn D, Hanson GH (2015) Untangling trade and technology: evidence from local labor markets. Econ J 125(May):621-646

Baldwin R, Robert-Nicoud F (2014) Trade-in-goods and trade-in-tasks: an integrating framework. J Int Econ 92(1):51-62

Baumgarten D, Geishecker I, Görg H (2013) Offshoring, tasks, and the skill-wage pattern. Eur Econ Rev 61:132-152

Bernard AB, Jensen JB, Schott PK (2006) Survival of the best fit: exposure to low-wage countries and the (uneven) growth of US manufacturing plants. J Int Econ 68(1):219-237

Borjas GJ, Freeman RB, Katz LF, Di Nardo J, Abowd JM (1997) How much do immigration and trade affect labor market outcomes? Brook Pap Econ Act 1997:1-90

Burstein, A., \& Vogel, J. (2011). Factor prices and international trade: A unifying perspective. NBER Working Paper No.16904). National Bureau of Economic Research

Cadarso MÁ, Gómez N, López LA, Tobarra MÁ (2008) The EU enlargement and the impact of outsourcing on industrial employment in Spain, 1993-2003. Struct Change Econo Dyn 19(1):95-108

Cahuc P, Carcillo S, Zylberberg A, McCuaig W (2014) Labor economics. MIT press, Cambridge

Card D, Lemieux T (2001) Can falling supply explain the rising return to college for younger men? A cohort-based analysis. Q J Econ 116(2):705-746

Card D, Di Nardo JE (2002) Skill biased technological change and rising wage inequality: some problems and puzzles. NBER Working Paper No. 8769. National Bureau of Economic Research 
Castellani D, De Benedictis L, Horgos D (2013) Can we really trust offshoring indices? Struct Change Econ Dyn 25:159-172

Castellani D, Mancusi ML, Santangelo GD, Zanfei A (2015) Special section: offshoring, immigration and the labour market: a micro-level perspective. Econ Polit Ind 42(2):157-162

Crinò R (2009) Offshoring, multinationals and labour market: a review of the empirical literature. J Econ Surv 23(2):197-249

Crinò R (2012) Service offshoring and the skill composition of labour demand. Oxf Bull Econ Stat 74(1):20-57

Dahl CM, Le Maire D, Munch JR (2013) Wage dispersion and decentralization of wage bargaining. J Labor Econ 31(3):501-533

Di Giovanni J, Levchenko AA (2009) Trade openness and volatility. Rev Econ Stat 91(3):558-585

Eaton J, Kortum S (2002) Technology, geography, and trade. Econometrica 70(5):1741-1779

Ebenstein A, Harrison A, McMillan M, Phillips S (2014) Estimating the impact of trade and offshoring on American workers using the current population surveys. Rev Econ Stat XCVI(4):581-595

Edwards L, Lawrence RZ (2010) US trade and wages: the misleading implications of conventional trade theory, NBER Working Paper No. 16106

Egger H, Egger P (2003) Outsourcing and skill-specific employment in a small economy: austria after the fall of the iron curtain. Oxf Econ Pap 55(4):625-643

Falk M, Wolfmayr Y (2005) Employment effects of trade in intermediate inputs with the EU Member States and Asia. Aussenwirtschaft 60(4):441-462

Falk M, Wolfmayr Y (2008) Services and materials outsourcing to low-wage countries and employment: empirical evidence from EU countries. Struct Change Econ Dyn 19:38-52

Federico S (2014) Industry dynamics and competition from low-wage countries: evidence on Italy. Oxford Bull Econ Stat 76(3):389-410

Feenstra RC (1998) Integration of trade and disintegration of production in the global economy. J Econ Perspect 12(4):31-50

Feenstra RC (2010) Offshoring in the global economy: microeconomic structure and macroeconomic implications. MA, MIT Press, Cambridge

Feenstra RC, Hanson GH (1999) The impact of outsourcing and high-technology capital on wages: estimates for the United States, 1979-1990. Q J Econ 114:907-941

Foster-McGregor N, Stehrer R, de Vries GJ (2013) Offshoring and the skill structure of labour demand. Rev World Econ 149(4):631-662

Frankel JA, Romer D (1999) Does trade cause growth? Am Econ Rev 89(3):379

Geishecker I, Görg H (2008) Winners and losers: a micro-level analysis of international outsourcing and wages. Can J Econ 41(1):243-270

Geishecker I, Görg H (2013) Services offshoring and wages: evidence from micro data. Oxf Econ Pap 65(1):124-146

Geishecker I, Görg H, Munch JR (2010) Do labour market institutions matter? Micro-level wage effects of international outsourcing in three European countries. Rev World Econ 146(1):179-198

Goos M, Manning A (2003) McJobs and MacJobs: the growing polarisation of jobs in the UK. Palgrave Macmillan, Basingstoke

Goos M, Manning A, Salomons A (2014) Explaining job polarization: routine-biased technological change and offshoring. Am Econ Rev 104(8):2509-2526

Grossman GM (2013) Heterogeneous workers and international trade. Rev World Econ 149(2):211-245

Grossman GM, Rossi-Hansberg E (2008) Trading tasks: a simple theory of offshoring. Am Econ Rev 98(5):1978-1997

Hertveldt B, Michel B (2013) Offshoring and the skill structure of labour demand in Belgium. De Econ 161(4):399-420

Hijzen A, Swaim P (2007) Does offshoring reduce industry employment? Natl Inst Econ Rev 201(1):86-96

Hijzen A, Görg H, Hine RC (2005) International outsourcing and the skill structure of labour demand in the United Kingdom. Econ J 115(506):860-878

Hummels D, Jørgensen R, Munch J, Xiang Ch (2014) The wage effects of offshoring: evidence from Danish matched worker-firm data. Am Econ Rev 104(6):1597-1629

Khandelwal A (2010) The long and short (of) quality ladders. Rev Econ Stud 77(4):1450-1476

Liu R, Trefler D (2008) Much ado about nothing: American jobs and the rise of service outsourcing to China and India, NBER Working Paper No. 14061 
Manning A (2011) Imperfect competition in the labour market. In: Ashenfelter O, Card DE (eds) Handbook of labor economics, vol 4B. Elsevier, Amsterdam, pp 973-1041

Michaels G, Natraj A, van Reenen J (2014) Has ICT polarized skill demand? Evidence from eleven countries over 25 years. Rev Econ Stat 96(1):60-77

Michel B, Rycx F (2012) Does offshoring of materials and business services affect employment? Evidence from a small open economy. Appl Econ 44(2):229-251

Parteka A, Wolszczak-Derlacz J (2015) Integrated industries-diversified earnings: the (missing) impact of offshoring on wages and wage convergence in the EU27. J Econ Inequal 13(3):325-350

Polgár ÉK, Wörz J (2010) No risk and some fun? Trade and wages in the enlarged European Union. Empirica 37(2):127-163

Rodríguez-Clare A (2010) Offshoring in a ricardian world. Am Econ J: Macroecon 2(2):227-258

Santos Silva MC, Tenreyro S (2006) The log of gravity. Rev Econ Stat 88(4):641-658

Schwörer T (2013) Offshoring, domestic outsourcing and productivity: evidence for a number of European countries. Rev World Econ 149(1):131-149

Sethupathy G (2013) Offshoring, wages, and employment: theory and evidence. Eur Econ Rev 62:73-97

Staiger D, Stock J (1997) Instrumental variables regression with weak instruments. Econometrica 65:557-586

Timmer MP, Los B, Stehrer R, Vries GJ (2013) Fragmentation, incomes and jobs: an analysis of European competitiveness. Econ Policy 28(76):613-661

Timmer MP, Dietzenbacher E, Los B, Stehrer R, de Vries GJ (2015) An illustrated user guide to the world input-output database: the case of global automotive production. Rev Int Econ 23(3):575-605

Wooldridge JM (2010) Econometric analysis of cross section and panel data. MIT press, Cambridge

Zellner A, Theil H (1962) Three stage least squares: simultaneous estimate of simultaneous equations. Econometrica 29:54-78 